Discussion Paper No. 2017-01

\title{
Central bank notes and black markets: the case of the Japanese economy during and immediately after World War II ${ }^{1}$
}

August, 2017

\author{
Makoto Saito ${ }^{2}$ \\ Hitotsubashi University
}

\begin{abstract}
Employing the Japanese case of large-scale black markets under extensive price controls in the years 1937 to 1949 , this paper investigates how much income leaked out of the formal economy into the black markets, and the extent to which the circulation of Bank of Japan (BoJ) notes helped the leaked income to flow back into the formal economy when the notes were eventually held as an instrument to conceal illicit income by the black marketers. According to our estimates, $6 \%$ to $30 \%$ of national income leaked into the black markets in the above period, while more than $40 \%$ of the leaked income returned to the treasury as massive seigniorage revenues in the last years of the war. Thanks to strong money demand from the black marketers, inflations were not too high during the war. After the war, however, the black marketers shifted their portfolios from BoJ notes to physical assets, thereby reducing money demand and accelerating inflations. This paper also demonstrates that the black markets helped to reserve physical resources for the post-control economy starting from the early 1950s.
\end{abstract}

Key words: black markets, central bank notes, wartime finance, price controls, economic controls.

1 The author cordially thanks seminar participants at Nagoya University, the Ministry of Finance, Keio University, Hitotsubashi University, the University of Tokyo, Kansai Macroeconomic Study Group, Osaka University, the Bank of Japan, Statistical Study Group, Hosei University, Waseda University, Ministry of Economy, Trade and Industry, Chuo University, the Cabinet Office, and Gakushuin University, and the NBER Japan Project for their valuable comments. In particular, he gratefully acknowledges comments, discussions, and encouragement from Raymond Fisman, Hiroshi Fujiki, Kyoji Fukao, Yasushi Iwamoto, Ryoji Koike, Shigenori Shiratsuka, Masato Shizume, Tetsuji Okazaki, Haruto Takeda, Juro Teranishi, and Kazuki Yokoyama.

2 Makoto Saito, Graduate School of Economics, Hitotsubashi University, makoto@econ.hit-u.ac.jp. 


\section{Introduction}

Central bank notes, in particular large denomination bills, are considered to be an effective instrument for black marketers to conceal illicit income thanks to their uninscribed nature, as Rogoff (2016) presents many cases in detail. Beyond such a microeconomic consideration, however, there seem to be several questions in regard to a macroeconomic relationship between central bank notes and black market transactions. This paper empirically examines the Japanese economy in the Sino-Japanese War (1937-1945) and the Pacific War (1941-1945) during World War II, and the postwar years of 1945 to 1949 , which were part of the occupation period ending in 1952. During the years 1937 to 1949 , the Japanese economy was controlled by rationing and price controls. In this period, large black markets developed because of extensive but ineffective price controls, ${ }^{3}$ while the Bank of Japan (BoJ) issued massive quantities of bank notes. Thus, this period is potentially suitable for a careful study of the macroeconomic interdependence between central bank note issuance and black markets.

We consider two macroeconomic phenomena observed during the period 1937 to 1949, both of which were historically uncommon but seemingly unrelated to each other. As statistical discrepancies in the national accounts demonstrate in Figure 1, aggregate expenditure exceeded aggregate income in nominal terms by more than $5 \%$ of nominal gross national expenditure (GNE) in this period. As also shown in Figure 1, however, Marshallian k, which is defined as the outstanding BoJ notes divided by nominal GNE, started to deviate upward from its long-run average of $10 \%$ in 1937 , peaked at around $50 \%$ in 1945 , and reverted quickly to $10 \%$ by 1949 . This paper presents a simple macroeconomic framework within which these two seemingly disconnected phenomena-large-scale leakages of national income and strong aggregate demand for BoJ notes—can be explained in a consistent manner.

This paper first proves that a statistical discrepancy between nominal aggregate expenditure and income serves as an exact measure of income leakages into black markets in the simultaneous presence of black market prices and official prices. Given this theoretical interpretation, 6\% to

3 While many papers, including Rockoff (1984) for the US and Williams (1945) for non-US countries, point out that extensive price controls triggered the emergence of black markets, little research has been done in terms of economy-wide interactions between the formal economy and black markets. 
$30 \%$ of national income leaked out of the formal economy into black markets in the years 1937 to 1949. As a result of the massive income leakages into the black markets, those in the formal economy, both public and private sectors, were subject to severe financial shortages in the sense that net national savings fell short of net investment plus net exports.

In addition, this paper establishes a theoretical relationship between such income leakages into black markets and aggregate demand for central bank notes. The circulation of BoJ notes helped the leaked income to return to the financially deficient formal economy, when BoJ notes were eventually held as an instrument for concealing illicit income by the black marketers. In the last years of the war (1943 to 1945), more than $40 \%$ of the leaked income returned to the treasury as massive seigniorage revenues thanks to strong money demand from the black markets, which in turn mitigated substantially the price impact of the massive issuance of BoJ notes. In this way, largely positive statistical discrepancies can be interpreted as evidence for income leakages into the black markets, while quite high Marshallian k can be elucidated as confirmation of strong money demand from the black marketers, who in turn received the income leaking from the formal economy.

This paper contributes to the literature on the measurement of the informal economy ${ }^{4}$ by presenting explicit theoretical foundations for such yardsticks. In the existing literature, statistical discrepancies between nominal aggregate expenditure and income have been frequently regarded as a proxy for the size of the underground economy (see O'Higgins (1989)). ${ }^{5}$ As Thomas (1999), Tanzi (1999), and others argue, however, such statistical discrepancies do not necessarily have theoretical justifications as a measure of the informal economy. ${ }^{6}$ This paper alternatively presents a theoretically convincing case where a statistical discrepancy serves as an exact measure of income leakages into black markets in the presence of price controls.

This paper also offers a theoretical framework in which aggregate demand for central bank

\footnotetext{
4 See Frey and Pommerehne (1982), Feige (1989), Schneider (2005), and Georgiou (2007) for a survey of this field.

5 In the context of the Japanese national accounts, Mizoguchi and Nojima (1993) and Mizoguchi (1996) make an informal statement that the presence of black markets was responsible for largely positive statistical discrepancies in the postwar EPA national accounts (EPA, 1964). ${ }_{6}$ In addition, econometric studies including Gartaganis and Goldberger (1955) and Adams and Janosi (1966) point out that statistical discrepancies in peacetime periods reflect various kinds of measurement errors.
} 
notes is tightly linked with income leakages into black markets. Without any explicit theoretical justification, several papers argue that monetary measures may serve as proxies for the scale of black market transactions. For example, cash/deposit ratios are proposed by Cagan (1958), Gutmann (1977), and Bhattacharyya (1990), while currency demand measured in terms of Marshallian k is proposed by Feige (1989). The justification for these measures is frequently based on a casual observation that black marketers hold central bank notes to conceal illicit income. This paper instead demonstrates an upward deviation of Marshallian k from its long-run average as exactly reflecting strong money demand from black markets, thereby overcoming the theoretical drawbacks involved in preceding papers.

Finally, this paper presents a case in which high tension between efficiency and inequality is induced by illegal transactions in a heavily regulated economy. Obviously, any resource allocation through illegal transactions involves uneven wealth distribution to illicit dealers. However, a role which was played potentially by transactions using BoJ notes and barter transactions with the black marketers during the controlled-economy period may be interpreted as a second-best response to heavy economic controls. According to our results, for example, the outstanding assets, which were accumulated mainly in the form of BoJ notes during the war, and durables and inventories after the war by the black marketers, reached close to the size of the national economy by the late 1940s. Consequently, there emerged extremely unfair distribution of wealth toward the black marketers, but illegal cash transactions and illicit barter transactions in the black markets helped to reallocate those resources from the controlled economy to the postcontrol economy, which finally took off after most economic controls were lifted in the early 1950s.

This paper is organized as follows. Section 2 offers a brief description of the price controls that were imposed during and immediately after the war. Section 3 presents a theoretical justification for the statistical discrepancy as an exact measure of income leakages into black markets, and a theoretical framework in which aggregate demand for central bank notes is tightly linked to income leakages into black markets. Section 4 interprets the Japanese national accounts as well as the monetary statistics of the 1930s and 1940s using the framework presented in Section 3. Section 5 concludes the paper. 


\section{A brief history of the controlled economy in the years 1937 to 1949}

\subsection{The price controls during and immediately after the war ${ }^{7}$}

A fundamental problem faced by the Japanese economy during and immediately after World War II was stagnant production. According to the EPA (1964), real gross national expenditure was sluggish in the 1940s; in 1934-1936 constant prices, real GNE was 13.4 billion yen in 1930, and 22.1 billion in 1939 , but only 20.1 billion in $1944,10.9$ in 1946 , and 16.2 billion in $1950 .{ }^{8}$ Among the possible factors responsible for the prolonged stagnant production in the 1940s, a shortage of imported goods was the most crucial. In particular, production by munitions factories, which were heavily dependent on imports of intermediate goods from the Allies, declined substantially because of a series of economic blockades imposed by the Allies starting in the late 1930s. Even after the war, the General Headquarters of the Allied Powers (the occupation army in Japan) imposed strict restrictions on imports with exceptions for humanitarian purposes. It was after these import restrictions were lifted for heavy oil in 1947 and for other commodities in 1948 that Japanese production started to recover from serious economic stagnation.

Given such a serious shortage of materials and products, the government was forced to prioritize the distribution of scarce resources; namely, to munitions industries during the war, and to heavy industries including coal and steel during the postwar reconstruction. At the same time, the government had to implement extensive price controls so that excess demand resulting from wide-ranging rationing might not lead to rapidly rising prices. ${ }^{9}$ For this purpose, the wartime government legislated the Temporary Import/Export Grading Measures Law (TIEGML), the Temporary Funds Adjustment Law (TFAL), and the Material Mobilization Plans (MMP) in 1937, the Total National Mobilization Law (TNML) in 1938, and the Productive Capacity Expansion Plans (PCEP) in 1939.

Initially under the TIEGML in 1937 and the TNML in 1938, and later by the Price Control Order (PCO) enacted in 1939, the government set official prices at extremely low levels for most final and intermediate goods. Both wages and housing rents were also heavily regulated by the

\footnotetext{
7 The description in this subsection is based on Nakamura $(1974,1983)$.

8 See column (1) in Table 5.

9 Nakamura (1983) describes in detail the legislation process of economic controls for the years 1937-1945.
} 
PCO. Accordingly, especially in intermediate goods markets, producers had a strong incentive to sell their own goods in black markets at higher prices and to retain illegal earnings off the books. At the same time, because of strict rationing, producers were forced to purchase goods through undercover dealings. Consequently, expensive intermediate goods obtained from black markets increased production costs, but producers had to disclose sales of all intermediate and final goods at the cheap official prices. Then, producers in official markets had to carry considerable losses, for which they were often compensated by government subsidies such as the subsidies to offset price differentials and the loss compensation. In addition, consumers had to purchase expensive goods from black markets in the final years of the war.

The police force launched a crackdown on illegal transactions in late 1938, but from 1941, it began weakening such control gradually, partly because of a shortage of officers and partly because of the frequent involvement of military personnel in undercover transactions. According to Kikuchi (1947) and Miwa (2015), as a consequence of ineffective material allocations under the MMP, some munitions factories were rationed unnecessarily, and they disposed of their excess rations of goods into illegal markets. In addition, Kikuchi (1947) documents that after munitions factories were forced to achieve extremely demanding production targets imposed by the Munitions of War Act in late 1943, they started to purchase a large amount of raw materials from illegal dealers. Nishida (1994) also points out that munitions factories purchased consumption goods from illegal dealers on behalf of their managers and employees in the period 1943-1945. In this way, munitions factories emerged as both sellers and buyers in black markets in the final years of the war.

While there are few time-series data for black market prices during the wartime period, ${ }^{10}$ Morita (1963) presents the effective wholesale/retail price indexes that reflect both official and black market transactions. The effective indexes, often called the Morita indexes, were compiled by the BoJ in the final years of the war and were employed in estimating nominal aggregate expenditure initially by the USSBS (1946) and later by the EPA (1964). ${ }^{11}$ As reported in Table 1,

10 Mizoguchi (1995) reports the black-to-official market price ratios of several consumption goods for the first quarter of 1944; for example, 7.45 for rice/wheat, 3.12 for vegetables, 4.73 for fish, 5.25 for meat, and 5.56 for seasonings.

11 As Morita (1963) explains, the effective wholesale price index was computed as the nominal amount of transactions by drafts divided by the quantity of commodity transactions, while the effective retail price index was computed as the nominal amount of transactions by cash divided by the quantity of commodity transactions. While these effective price indexes (the Morita indexes) 
the effective-to-official price ratio increased from 1.08 in 1940 to 1.45 in 1944 for wholesale prices, and from 1.07 in 1940 to 1.93 in 1944 for retail prices. ${ }^{12}$

The extensive rationing and price controls were maintained even after the war. The PCO was replaced by the Price Control Law in 1946, while the MMP was switched to the Material Supply and Demand Planning Program in 1945, which was reformulated as the Priority Production System in 1946. In the aftermath of the war, the government concentrated material and financial resources in heavy industries, in particular coal and steel. As in the wartime period, the government offered subsidies to offset price differentials for heavy industry products.

According to the Bank of Japan (1966), the black-to-official market price ratio was fairly high for production goods; it was 7.2 in 1946, 5.3 in 1947, 2.9 in 1948, and 1.7 in 1949. The government started to lift price controls as well as resource rationing from early 1949, when the Dodge Line, which was proposed as a fiscal reconstruction plan by the General Headquarters, was implemented. By the early 1950s, the black markets disappeared completely.

\subsection{Government subsidies to offset price differentials}

As mentioned above, during the wartime period, producers in munitions industries always carried enormous losses as a result of their purchases of expensive intermediate goods in black markets and their sales of cheap final goods in official markets. A substantial fraction of such losses was compensated for by the subsidies and loss compensation from the government. According to Nakamura (1974), for example, the Japan Coal Company was founded as a public institution to control coal markets in 1939. The company purchased coal from all domestic mines at cost prices and sold them to final users through private coal companies at official prices, which were much cheaper than the cost prices. In 1944, the official price was about half of the cost price.

The corporate losses resulting from the extensive price controls were even larger for heavy industries after the war. The losses were initially financed from the Reconstruction Finance Bank

were recognized as far from perfect measures among experts including even Yuzo Morita, there was no alternative to the Morita index as a measure of wartime transaction prices.

12 Before most final and intermediate goods were regulated heavily by the PCO in 1939, the BoJ official price indexes included not only regulated prices, but also unregulated ones. Thus, the BoJ's official price indexes and the effective price indexes (the Morita indexes) were close to each other under price controls in the late 1930s. 
(RFB), which was backed by the BoJ's underwriting, and were later subsidized or compensated for by the government. Miwa and Ramseyer (2004), employing the accounting data of Hokkaido Colliery and Steamship Company, document that the official coal prices were updated extremely slowly despite persistent galloping inflations, and they equaled only around $40 \%$ of the cost prices in early 1948.

In this way, most losses resulting from such large price differentials were eventually covered by the government subsidies and the loss compensation. Accordingly, these losses were transferred from private companies to the government, which in turn financed these subsidies mainly by letting the BoJ underwrite public bonds as described in the next subsection. The subsidies and loss compensation paid to heavy industries accounted for $17.8 \%, 23.8 \%$, and $30.2 \%$ of general account expenditure in 1947, 1948, and 1949 respectively. By the order of the General Headquarters, however, the government could not pay any subsidy or compensation for corporate losses by the early 1950 s.

\subsection{Massive issues of BoJ notes during and immediately after the war}

Let us briefly describe some institutional details of the large-scale money issuance developed by the BoJ during the wartime and postwar periods. Finance Minister Takahashi Korekiyo initiated the large-scale money issuance by requesting the BoJ to underwrite new issues of public bonds directly and to issue in turn BoJ notes to the government in November 1932. Even after the assassination of Takahashi in 1936, the government continued the money issuance throughout World War II.

The BoJ's underwriting was initially introduced not as a fiscal instrument for the government but as a macroeconomic stimulus measure. While the BoJ directly underwrote public bonds during the years 1932-1936, it resold to the private banks more than $90 \%$ of what it purchased directly from the government. That is, the BoJ withdrew most of the newly issued bank notes from the economy. This implies that the government eventually financed its own deficit by borrowing not from the BoJ but from the private banks. ${ }^{13}$ As analyzed in detail by Shibamoto and Shizume (2014), the above monetary policy together with suspension of the gold standard indeed

13 See Shima (1983). 
worked effectively to stimulate the economy mainly through a marked depreciation of the yen.

However, the direct underwriting by the BoJ had been employed as a powerful fiscal tool since the Sino-Japanese War began in 1937. Even after 1937, the BoJ continued to resell most of their direct purchases of public bonds to the private banks, but the private banks financed the bond purchases from the BoJ not with deposits from private savings, but with credit provided directly by the BoJ. This was equivalent to the government receiving credit from the BoJ via the private banks. ${ }^{14}$ After February 1942, the upper limit on the issue of BoJ notes was determined solely by the Minister of Finance. ${ }^{15}$

Even in the aftermath of the war, the BoJ kept underwriting public bonds directly from the government. While the General Headquarters prohibited the BoJ from underwriting long-term public bonds in November 1945, the BoJ was still allowed to underwrite short-term public bonds. After the Public Finance Act was legislated in March 1947, the BoJ could not underwrite any public bonds in principle. However, the BoJ underwrote the short-term bonds issued by the Reconstruction Finance Bank (RFB), which was founded as a public financial institution in January 1947. The RFB was not classified as a governmental body, and the BoJ was able to underwrite the RFB short-term bonds even under the Public Finance Act. By underwriting the RFB bonds, the BoJ issued bank notes to the value of 39.6 billion yen in 1947, and 37.2 billion yen in 1948 , which accounted for about $30 \%$ of the total issuance in those years. However, the RFB was not allowed to issue any additional bonds from April 1949 under the direction of the General Headquarters. In this way, the BoJ developed large-scale direct underwriting of public and quasipublic bonds from November 1932 to March 1949.

\subsection{A possible macroeconomic interaction between the circulation of BoJ notes and the black markets: a descriptive explanation}

\subsubsection{Two channels by which the leaked income returned to the formal economy}

\footnotetext{
14 The BoJ provided funds to the private banks, which in turn put up the public bonds as collateral at the BoJ. Because the lending rate charged by the BoJ was lower than the yield on the long-term public bonds, the private banks were willing to purchase the public bonds by receiving inexpensive credit from the BoJ.

15 Japan suspended the gold standard in December 1931, but the outstanding BoJ notes had been constrained by the amount of specie reserves up to January 1942.
} 
Before presenting a theoretical framework in Section 3, this subsection describes the income transfers between the formal economy and the black markets during and after the war. One of the most serious problems of the controlled economy was that the private agents in the formal economy received sales and wages at cheap official prices, but made some payments at expensive black market prices. Accordingly, private firms carried enormous losses, while consumers had an excess of payments over revenues. However, the government could not impose taxes on financially deficient private agents or issue public bonds to them in order to finance large-scale deficits resulting from war expenditures, the reconstruction costs, and the subsidies for covering private corporate losses. The flip side of such severe financial shortages experienced by the formal economy was that the black marketers received the income leaking from the formal economy as illegal margins resulting from purchases from the formal agents at cheap prices and sales to them at expensive prices.

There were potentially two ways to return the hidden income from the black markets to the formal economy. In the first channel, the private agents in the formal economy bartered directly with the illegal dealers by exchanging inventories held by firms and durables held by households for resources from the black marketers. For large-scale illegal transactions, the private agents in the formal economy employed housing and land as a medium of exchange. ${ }^{16}$ The undercover dealers in turn held inventories, durables, and immovable properties as store of value. Note that the durables and inventories, which were produced previously and stored by the formal private agents, were exchanged for the resources that were produced currently and obtained through illegal transactions by the black marketers.

As the second channel, the BoJ's direct underwriting of public bonds served as the inevitable fiscal instrument for the government, because (i) the government could not obtain any more resources from the private agents suffering from the income leakage into the black markets, (ii) the government as a legitimate body could not deal directly with the black marketers, but it could

\footnotetext{
16 When the PCO was enacted in 1939, house rents were heavily controlled, but the prices of housing and land were beyond the scope of the Order. In 1939, newly built houses were targeted by the price controls, but secondhand homes were not. Consequently, the owners of secondhand homes had a strong incentive to sell their houses instead of renting them at cheap rents. According to Ono (2007), old houses were traded actively as a type of speculation in black housing markets during the years 1943 to 1944 .
} 
deal with the BoJ as another legitimate body, (iii) BoJ notes newly issued to the government ultimately moved into the black markets because the total expenditure made by those in the formal economy exceeded the total income received by them, and (iv) the black marketers in turn held newly issued BoJ notes to conceal illicit income by exploiting their uninscribed nature. ${ }^{17}$ In this way, strong money demand from the black marketers, who received a part of the national income leaking from the formal economy, created large seigniorage revenues for the financially deficient government.

\subsubsection{The circulation of BoJ notes during and after the war}

It is quite difficult to obtain precise information regarding how BoJ notes circulated in the black markets under the extensive price controls, but there was one precious occasion where BoJ notes, which had been handed over from one illegal dealer to another, came to light in the formal economy. This occurred when the BoJ forced the holders of BoJ notes to exchange old bills for new bills in February 1946.18 Their policy purpose was to identify the black market income as precisely as possible and to impose capital levies on it of as much as $100 \%{ }^{19}$

According to the Ministry of Finance (1986), the amount of outstanding BoJ notes decreased dramatically from 61.8 billion yen on February $18^{\text {th }}, 1946$ to 15.2 billion yen on March $12^{\text {th }}$ following the official announcement on February $16^{\text {th }}$. The BoJ eventually collected 50.3 billion yen in old bills, of which 9.0 billion yen were collected from the rural districts of Southern Kanto, Tokai, and Kinki, while 8.1 billion yen were collected from the urban districts of Tokyo and Osaka. These statistics indicate that illegal dealings were most active in the agricultural and commercial sectors. After new bills began to circulate, the amount of outstanding BoJ notes began rising again

17 Most of the public bonds were issued as uninscribed during and immediately after the war, but their coupons and principals needed to be cashed at financial institutions where identification of bond holders was required.

18 More precisely, the government officially announced the Emergency Financial Measure on the evening of Saturday, February $16^{\text {th }}$. The measure included the following provisions. First, old bills would cease being legal tender after March $2^{\text {nd }}$. Second, the deposits at financial institutions using old bills could be made until March $7^{\text {th }}$ (later revised to $9^{\text {th) }}$. Third, withdrawals from deposits using new bills were severely restricted.

19 In December 1945, the government suggested that the BoJ might collect old bills in exchange for new bills. Surprised by the intention of the government and the BoJ, major illegal dealers rushed to trade any cash on hand for physical materials and food, and they in turn refused to sell their inventories for old bills. Consequently, a substantial portion of the black markets disappeared until the exchange for new bills was completed in March 1946. 
to 136.3 billion yen as of June 1947, and 230.5 billion yen as of June 1948. The majority of new bills were held within the commercial sector rather than the agricultural sector. While the Ministry of Finance (1986) suggests that a substantial proportion of new bills still continued to be held by the illegal dealers, most of new bills were actually held for transaction purposes by those in the formal economy as shown in Section 4.5.

\section{A theoretical relationship between black markets and money demand under price controls}

\subsection{A simple model of possible effects of price controls on the national accounts}

This subsection demonstrates that if official and black market prices exist simultaneously, then a positive statistical discrepancy between aggregate expenditure and income in the national accounts serves as an exact measure of income leakages into black markets. The historical situation described in Section 2.1 may be simplified as follows. In corporate accounting, producers disclose sales of all final and intermediate goods at official prices, while the purchases of intermediate goods from underground dealings are recorded at black market prices. The margins earned by selling to underground dealers are off the books. However, consumers purchase some consumption goods from black markets.

Let us formalize below the possible effects of price controls on the national accounts. Here, it is assumed that the purchases of goods are valued at transaction prices, and the sales of goods are valued at official prices. The black market margins are not reported at all. Here, $P_{\text {inter }}^{o m}, P_{\text {final }}^{o m}$, $P_{\text {inter }}^{b m}$, and $P_{\text {final }}^{b m}$ denote official and black market prices for intermediate and final goods respectively. For intermediate goods, $V_{\text {inter }}^{o m}$ and $V_{\text {inter }}^{b m}$ are traded in official and black markets. For final goods, $V_{\text {final }}^{\text {om }}$ and $V_{\text {final }}^{\text {bm }}$ are traded in each market. The transactions are summarized as follows.

\begin{tabular}{|c|c|c|}
\hline & Official markets & Black markets \\
\hline Intermediate goods & $P_{\text {inter }}^{\text {om }} V_{\text {inter }}^{\text {om }}$ & $P_{\text {inter }}^{b m} V_{\text {inter }}^{b m}$ \\
\hline Final goods & $P_{\text {final }}^{\text {om }} V_{\text {final }}^{\text {om }}$ & $P_{\text {final }}^{b m} V_{\text {final }}^{b m}$ \\
\hline
\end{tabular}

According to the above valuation rule, the nominal expenditure on all final goods $Y_{n}^{E}$ is computed as follows. Note that a variable with a lower subscript $n$ denotes a nominal variable. 


$$
\begin{aligned}
& Y_{n}^{E}=P_{\text {final }}^{\text {om }} V_{\text {final }}^{o m}+P_{\text {final }}^{b m} V_{\text {final }}^{b m} \\
& =P_{\text {final }}^{\text {om }}\left(V_{\text {final }}^{\text {om }}+V_{\text {final }}^{b m}\right)+\left(P_{\text {final }}^{b m}-P_{\text {final }}^{\text {om }}\right) V_{\text {final }}^{b m}
\end{aligned}
$$

Nominal aggregate income, measured as value added $Y_{n}^{V A}$, is calculated as

$$
\begin{aligned}
& Y_{n}^{V A}=P_{\text {inter }}^{o m}\left(V_{\text {inter }}^{o m}+V_{\text {inter }}^{b m}\right)+P_{\text {final }}^{o m}\left(V_{\text {final }}^{o m}+V_{\text {final }}^{b m}\right)-\left(P_{\text {inter }}^{o m} V_{\text {inter }}^{o m}+P_{\text {inter }}^{b m} V_{\text {inter }}^{b m}\right) . \\
& =P_{\text {final }}^{o m}\left(V_{\text {final }}^{o m}+V_{\text {final }}^{b m}\right)-\left(P_{\text {inter }}^{b m}-P_{\text {inter }}^{o m}\right) V_{\text {inter }}^{b m}
\end{aligned}
$$

Finally, the unreported margin in black markets $Y_{n}^{b m}$ corresponds to

$$
Y_{n}^{b m}=\left(P_{\text {final }}^{b m}-P_{\text {final }}^{o m}\right) V_{\text {final }}^{b m}+\left(P_{\text {inter }}^{b m}-P_{\text {inter }}^{o m}\right) V_{\text {inter }}^{b m} .
$$

As equations (1) and (2) imply, aggregate expenditure increases by the additional cost of final goods purchased from black markets, while aggregate income decreases by the additional cost of intermediate goods procured from illegal transactions. Consequently, the statistical discrepancy between aggregate expenditure and aggregate income $S D_{n}$ is exactly equal to the unreported illegal margin.

$$
\begin{aligned}
& S D_{n}=Y_{n}^{E}-Y_{n}^{V A} \\
& =\left(P_{\text {final }}^{b m}-P_{\text {final }}^{\text {om }}\right) V_{\text {final }}^{b m}+\left(P_{\text {inter }}^{b m}-P_{\text {inter }}^{o m}\right) V_{\text {inter }}^{b m} \\
& =Y_{n}^{b m}
\end{aligned}
$$

In this way, a part of aggregate income leaks from formal markets into black markets, amounting to a statistical discrepancy $S D_{n}$, or the unreported margins earned by illegal dealers $Y_{n}^{b m}$.

Given nominal aggregate expenditure and nominal aggregate income given by equations (1) and (2), the GNE and GNI deflators are defined as follows.

$$
\begin{aligned}
& P^{G N E}=\frac{P_{\text {final }}^{o m}\left(V_{\text {final }}^{o m}+V_{\text {final }}^{b m}\right)+\left(P_{\text {final }}^{b m}-P_{\text {final }}^{o m}\right) V_{\text {final }}^{b m}}{V_{\text {final }}^{o m}+V_{\text {final }}^{b m}} \\
& =P_{\text {final }}^{o m}+\left(P_{\text {final }}^{b m}-P_{\text {final }}^{o m}\right) \frac{V_{\text {final }}^{b m}}{V_{\text {final }}^{o m}+V_{\text {final }}^{b m}} \\
& P^{G N I}=\frac{P_{\text {final }}^{o m}\left(V_{\text {final }}^{o m}+V_{\text {final }}^{b m}\right)-\left(P_{\text {inter }}^{b m}-P_{\text {inter }}^{o m}\right) V_{\text {inter }}^{b m}}{V_{\text {final }}^{o m}+V_{\text {final }}^{b m}} \\
& =P_{\text {final }}^{o m}-\left(P_{\text {inter }}^{b m}-P_{\text {inter }}^{o m}\right) \frac{V_{\text {inter }}^{b m}}{V_{\text {final }}^{o m}+V_{\text {final }}^{b m}}
\end{aligned}
$$

That is, $P^{G N E}>P^{o m}>P^{G N I}$ holds. If $P_{\text {final }}^{o m}=P_{\text {inter }}^{o m}=P^{o m}$ and $P_{\text {final }}^{b m}=P_{\text {inter }}^{b m}=P^{b m}$, then the 
real share of black markets can be computed from these prices.

$$
\frac{V_{\text {inter }}^{b m}+V_{\text {final }}^{b m}}{V_{\text {final }}^{o m}+V_{\text {final }}^{b m}}=\frac{\frac{P^{G N E}-P^{G N I}}{\frac{P^{o m}}{P^{o m}}-1}}{P^{b m}}
$$

\subsection{Income leakages into black markets and aggregate demand for central bank notes}

In this subsection, the argument presented in Section 3.1 is translated into a more realistic setup of the national accounts. The following assumptions are made for this purpose. (i) An economy is closed. (ii) Any expenditure is evaluated in terms of transaction prices, which reflect both black market and official prices. (iii) Transaction prices of final goods increase by indirect taxes, and decrease by subsidies. (iv) Even if durables held at home and inventories concealed at factories are bartered illegally for resources from black marketers, any decline in inventories at household and corporate sectors in a formal economy is not recorded in the national accounts. (v) Nominal rents on public capital are zero.

Given a positive statistical discrepancy between aggregate expenditure and income $\left(S D_{n, t}>0\right)$, the saving-investment equality no longer holds in the national accounts. Let us start from

$$
\begin{aligned}
& Y_{n, t}^{E}=C_{n, t}^{P}+C_{n, t}^{G}+P_{t}^{I}\left(K_{t}^{P}-K_{t-1}^{P}+\delta K_{t-1}^{P}\right)+P_{t}^{I}\left(K_{t}^{G}-K_{t-1}^{G}+\delta K_{t-1}^{G}\right), \\
& =Y_{n, t}^{V A}+S D_{n, t}>Y_{n, t}^{V A}
\end{aligned}
$$

where $C_{n, t}^{P}$ and $C_{n, t}^{G}$ denote nominal private and government consumption in terms of transaction prices, $K_{t}^{P}$ and $K_{t}^{G}$ designate real capital of both private and public sectors, and $P_{t}^{I}$ and $\delta$ signify transaction prices of investment goods and depreciation rates. Aggregate value added at transaction prices $\left(Y_{n, t}^{V A}\right)$ decreases relative to aggregate expenditure at transaction prices $\left(Y_{n, t}^{E}\right)$ by a statistical discrepancy $\left(S D_{n, t}\right)$.

Then, net national savings (the right side of the inequality below) are short of net investment (the left side).

$$
P_{t}^{I}\left(K_{t}^{P}-K_{t-1}^{P}\right)+P_{t}^{I}\left(K_{t}^{G}-K_{t-1}^{G}\right)>Y_{n, t}^{V A}-\left(C_{n, t}^{P}+C_{n, t}^{G}\right)-\delta P_{t}^{I}\left(K_{t-1}^{P}+K_{t-1}^{G}\right)
$$

That is, those in a formal economy, both private and public sectors, suffer from financial shortages. As discussed in Section 2.4.1, private agents can cover such financial shortages by bartering 
durables and inventories for resources from black marketers, while a government can finance fiscal deficits by seigniorage revenues by issuing central bank notes indirectly to illegal dealers.

Let us derive the budget constraints of private agents and a government in a formal economy. First, private agents in a formal economy are subject to the following budget constraint:

$$
\begin{aligned}
& C_{n, t}^{P}+P_{t}^{I}\left(K_{t}^{P}-K_{t-1}^{P}+\delta K_{t-1}^{P}\right)+\left(M_{n, t}^{F}-M_{n, t-1}^{F}\right)+\left(B_{n, t}-B_{n, t-1}\right), \\
& =R_{n, t}^{P} P_{t}^{I} K_{t-1}^{P}+W_{n, t} L_{t}+i_{t} B_{n, t-1}-T_{n, t}^{d i r}+B T_{n, t}
\end{aligned}
$$

where $M_{n, t}^{F}, T_{n, t}^{\text {dir }}$, and $B T_{n, t}$ denote demand for central bank notes from a formal economy, direct taxes, and resources obtained from black markets by barter transactions, respectively. By assumption (iii), both indirect taxes $\left(T_{n, t}^{\text {ind }}\right)$ and subsidies $\left(S_{n, t}\right)$ are reflected in transaction prices of final goods. $R_{n, t}^{P}, W_{n, t}, i_{t}$, and $L_{t}$ signify nominal rents on private capital, nominal wages, nominal rates of interest, and labor supply. $B_{n, t}$ represents outstanding public bonds held by private agents, excluding public bonds held by a central bank. By assumption (iv), any decline in household and corporate inventories induced by barter transactions with illegal dealers is not recorded in the national accounts.

Second, a government's budget constraint is formulated as

$$
\begin{aligned}
& C_{n, t}^{G}+P_{t}^{I}\left(K_{t}^{G}-K_{t-1}^{G}+\delta K_{t-1}^{G}\right)+S_{n, t}+i_{t} B_{n, t} \\
& =\left(T_{n, t}^{\text {dir }}+T_{n, t}^{\text {ind }}\right)+\left(M_{n, t}^{S}-M_{n, t-1}^{S}\right)+\left(B_{n, t}-B_{n, t-1}\right),
\end{aligned}
$$

where $M_{n, t}^{S}$ designates aggregate money supply, and $M_{n, t}^{S}-M_{n, t-1}^{S}$ corresponds to seigniorage revenues. By assumption (v), nominal rents on public capital are zero.

By assumption (iii), aggregate income at factor prices is equal to aggregate value added at transaction prices minus net indirect taxes (indirect taxes net of subsidies, $T_{n, t}^{\text {ind }}-S_{n, t}$ ). Then, aggregate (gross) income at factor prices is determined according to capital $\left(R_{n, t}^{P} P_{t}^{I} K_{t-1}^{P}\right)$ and labor income $\left(W_{n, t} L_{t}\right)$.

$$
Y_{n, t}^{V A}-\left(T_{n, t}^{\text {ind }}-S_{n, t}\right)=R_{n, t}^{P} P_{t}^{I} K_{t-1}^{P}+W_{n, t} L_{t}
$$

Either capital income or labor income improves with the help of subsidies from a government. Note that the amount of aggregate income at factor prices is unchanged despite direct taxes, which serve only as income transfers between a government and private agents within a formal economy.

Black marketers, however, allocate income leakages from a formal economy between adding central bank notes to their portfolios (cash transactions) and providing resources through barter 
transactions with private agents in a formal economy.

$$
S D_{n, t}=\left(M_{t}^{B}-M_{t-1}^{B}\right)+B T_{n, t},
$$

where $M_{t}^{B}$ stands for demand for central bank notes from black markets.

Putting together equations (8) to (12) leads to

$$
\left(M_{n, t}^{S}-M_{n, t-1}^{S}\right)-\left(M_{n, t}^{F}-M_{n, t-1}^{F}\right)=M_{n, t}^{B}-M_{n, t-1}^{B}=S D_{n, t}-B T_{n, t}
$$

That is, aggregate money supply in excess of money demand from a formal economy (the left side of equation (13)) is now absorbed by money demand from black markets $\left(M_{n, t}^{B}-M_{n, t-1}^{B}\right)$, which in turn comes from a part of income leakages into black markets $\left(S D_{n, t}-B T_{n, t}\right)$.

As in Cagan (1956), normal money demand from a formal economy is specified as proportional to nominal aggregate expenditure $\left(Y_{n, t}^{E}\right)$ under a unit income elasticity with small negative impacts of nominal rates of interest $i_{t}$. That is, Marshallian $\mathrm{k}$ is decreasing in nominal rates of interest; $\frac{M_{t}^{F}}{Y_{n, t}^{E}}=m\left(i_{t}\right)$, where $m^{\prime}\left(i_{t}\right)<0$. Unless money demand is extremely interest sensitive in the neighborhood of zero nominal interest rates, then $\frac{M_{t}^{F}}{Y_{n, t}^{E}}$ can be approximated as a fixed rate $m$. As reported in the last column of Table 2, the nominal rate of interest was indeed above $3 \%$ in the years 1937 to 1949 . Using this fact, equation (13) reduces to

$$
\left(M_{n, t}^{S}-M_{n, t-1}^{S}\right)-m\left(Y_{n, t}^{E}-Y_{n, t-1}^{E}\right)=M_{n, t}^{B}-M_{n, t-1}^{B},
$$

and it is further rearranged as

$$
\left(\frac{M_{n, t}^{S}}{Y_{n, t}^{E}}-m\right)-\left(\frac{M_{n, t-1}^{S}}{Y_{n, t-1}^{E}}-m\right)=\frac{M_{t}^{B}-M_{t-1}^{B}}{Y_{n, t}^{E}}-\frac{Y_{n, t}^{E}-Y_{n, t-1}^{E}}{Y_{n, t}^{E}}\left(\frac{M_{n, t-1}^{s}}{Y_{n, t-1}^{E}}-m\right) .
$$

According to equation (15), Marshallian k deviates upward from its normal rate $m$ to the extent that money demand is strong from black markets $\left(\frac{M_{t}^{B}-M_{t-1}^{B}}{Y_{n, t}^{E}}>0\right)$, while nominal economic $\operatorname{growth}\left(\frac{Y_{n, t}^{E}-Y_{n, t-1}^{E}}{Y_{n, t}^{E}}\right)$ and previously high Marshallian k relative to $m\left(\frac{M_{n, t-1}^{s}}{Y_{n, t-1}^{E}}-m>0\right)$ work jointly to reduce Marshallian k $\left(\frac{M_{n, t}^{S}}{Y_{n, t}^{E}}\right)$.

Note that the flow of funds differs considerably between the cases with and without black 
markets. In a standard model without black markets, the statistical discrepancy is always zero. As shown in Figure 2-1, a government finances fiscal deficits by issuing both central bank notes and public bonds to households. In this case, the new issue of central bank notes is absorbed completely by household savings. However, once a part of aggregate income leaks from a formal economy into black markets, not only households, but also black marketers hold central bank notes, which are newly injected by a central bank's direct underwriting. As shown in Figure 2-2, new central bank notes are held by both those in a formal economy who expand transaction demand, and those in black markets who are interested in concealing illicit income.

\section{Interpretations of statistical discrepancies and Marshallian k in the years 1937 to 1949}

\subsection{On constructions of the national accounts}

We interpret the wartime and postwar EPA national accounts and monetary statistics using the theoretical frameworks presented in Section 3. The EPA (1964) compiled the annual national accounts from 1930 to 1951 with 1934-1936 as the base years, but no data for 1945 were available there. ${ }^{20}$ However, data on the value of outstanding BoJ notes and the wholesale/retail price indexes (official price indexes) are available from the Bank of Japan (1966) without any missing observations.

There are three issues to be addressed regarding the EPA national accounts. First, the expenditure account was constructed using transaction prices recorded by the Morita index rather than official prices. ${ }^{21}$ For example, the consumption expenditure series from several productionside statistics were first valued item by item at the official prices. Then, these series were adjusted by the effective retail price index (Morita index) explained in Section 2.1, which reflected both official and black market prices. As shown in Table 1, the Morita indexes (the effective prices) and the GNE deflator indeed behave similarly in relation to the official prices (the wholesale/retail prices). In this way, the underestimation of expenses driven by cheaper official prices was corrected to some extent by using the effective price indexes (Morita indexes) to measure transaction prices

20 Ohkawa et al. (1974) construct the Japanese national accounts for the years 1885-1940. Fukao et al. (2015) present a more comprehensive version of the Japanese national accounts for the period 1874-2008. Jean-Pascal et al. (2016) present a brief history of the Japanese national accounts.

${ }^{21}$ See Mizoguchi and Nojima (1993). 
in the expenditure account. For the postwar data, black market prices were surveyed directly by the BoJ and were considered explicitly in constructing the expenditure account.

Second, the EPA national accounts computed aggregate income independent of the expenditure account. On the one hand, employee compensation was aggregated from several surveys of the wages and the labor force. On the other hand, corporate income was aggregated from corporate tax return data with due consideration to differences between business and taxation accounting. In the taxation data, black market margins were unlikely to be included. Note that the computation of corporate income differs entirely between the EPA national accounts and the recent versions of the Japanese national accounts. In the latter accounts, corporate income is never aggregated directly from corporate tax returns but instead is computed as a residual by subtracting the estimated employee compensation from aggregate value added. ${ }^{22}$

Third, while the Japanese government and private corporations conducted military and economic activities in overseas territories during the wartime period, the domestic (interior) economy was almost completely separated from the economies of the overseas territories in terms of income transfers. As documented in detail by Hara (1976), under the strict capital controls coupled with the fixed exchange rate system, the income transfers to/from the overseas territories were constrained tightly. The relative size of the net income transfers was much less than one percent of nominal GNE during the wartime period. Most overseas military and industrial activities were financed within each territory through the bank notes that were issued by the reserve/central banks in the occupied territories. ${ }^{23}$ Accordingly, the level of aggregate income in the domestic economy was influenced only slightly by the scale and scope of the economic activity in the overseas territories.

\footnotetext{
22 According to Yamamoto (2011), France, England, Finland, Germany, Norway, and Spain follow the same method used currently by the Japanese government. In Canada, the US, and Australia, however, corporate income is aggregated from corporate accounting data together with corporate tax return data. Fujiwara and Ogawa (2016) compute aggregate corporate income from tax return data for the recent Japanese economy.

${ }^{23}$ Hattori and Oguro (2016) estimate the amount of seigniorage revenues generated from direct underwriting of Japanese public debts by both the central banks in the colonial territories and the reserve banks in the occupied territories. Saito (2017) analyzes in detail how the war expenditures in the Japanese occupied territories were financed through the colonial central banks and the local reserve banks during the Pacific War.
} 


\subsection{Approximation of nominal GNE and minimum statistical discrepancy in 1945}

As mentioned above, the EPA (1964) failed to report any statistics for 1945. Here, both nominal GNE and a minimum value of the statistical discrepancy are approximated for 1945 in a rather heroic manner. First, the nominal GNE of 1945 is approximated as follows. ${ }^{24}$ The ratio between the 1944 and 1945 values of real GDP is obtained from Mizoguchi and Nojima (1993); that is, 7.4 trillion yen in 1944 versus 5.6 trillion yen in 1945 (1955 constant prices). Then, the 1945 value of real GNE is computed as 15.3 billion yen given that the EPA (1964) reports its 1944 value as 20.1 billion yen in $1934-1936$ constant prices $\left(20.1 \times \frac{5.6}{7.4}\right)$. The GNE deflator is chosen as 7.5 such that $\frac{P_{1945}^{G N E}}{P_{1945}^{W P I}}=\frac{1}{2}\left(\frac{P_{1944}^{G N E}}{P_{1944}^{W P I}}+\frac{P_{1946}^{G N E}}{P_{1946}^{W P I}}\right)$ can hold under the assumption that the GNE deflator $\left(P_{t}^{G N E}\right)$ and the wholesale price index $\left(P_{t}^{W P I}\right)$ moved smoothly between the years 1944 and 1946 . Thus, the 1945 value of nominal GNE is approximated as 114.5 billion yen by the product of the above computed real GNE and GNE deflator $(15.3 \times 7.5)$.

Second, the minimum value of the statistical discrepancy is obtained for 1945 from equations (13) and (14).

$$
S D_{n, 1945} \geq\left(M_{n, 1945}^{S}-M_{n, 1944}^{S}\right)-m\left(Y_{n, 1945}^{E}-Y_{n, 1944}^{E}\right)=M_{n, 1945}^{B}-M_{n, 1944}^{B}
$$

That is, the minimum value of the statistical discrepancy is determined using the value of additional money demand from the black markets. From 1944 to 1945, aggregate money supply expanded by 37.7 billion yen from 17.7 billion yen to 55.4 billion yen, while as estimated above, nominal GNE increased by 40.0 billion yen from 74.5 billion yen to 114.5 billion yen. Given that $m$ is set at $10 \%$, the statistical discrepancy $S D_{n, 1945}$ is computed as at least 33.7 billion yen or $29.4 \%$ of nominal GNE as follows: $37.7-0.1 \times 40.0$.

\subsection{Largely positive statistical discrepancies}

Let us first examine the relative magnitude of the statistical discrepancies of the EPA national accounts. All nominal macroeconomic variables are expressed below in terms of their ratio to nominal GNE. As shown in Figure 3, the sum of net investment and net exports, computed from

24 Yasushi Iwamoto proposed the method by which the 1945 value of nominal GNE is computed. 
the expenditure account, exceeded net national savings, calculated from the income account in the years 1937 to 1949. Consequently, there emerged largely positive statistical discrepancies of more than 5\% of nominal GNE in these years. Before 1937 and after 1949, however, net investment plus net exports was close to net savings, and the statistical discrepancy was close to zero. In this way, the national accounts recorded large-scale income leakages into the black markets in the period in which the Japanese economy had been subject to extensive price controls.

During the wartime period, the discrepancy ratio peaked temporarily at $11.8 \%$ in 1938 , and it declined gradually to $6.4 \%$ in 1941 . Then, the ratio increased again gradually to $10.9 \%$ in 1944 . Given the minimum value of the statistical discrepancy estimated in Section 4.2, the ratio reached at least $29.4 \%$ in 1945 . That is, at least one third of the national income leaked into black markets just before and after the war's end (August, 1945).

Such wartime movements in the discrepancy ratio can be interpreted broadly as reflecting several institutional aspects of black market activities. The ratio was high immediately after the government controls were implemented in 1937. One possible reason for this immediate increase was that ineffective rationing helped to create black markets from the very beginning of rationings and price controls. ${ }^{25}$ From late 1938, stronger surveillance on illegal transactions by the police contributed to a decline in the ratio. However, the ratio began to increase again from 1941 partly because of a reduction in the size of the police force, and partly because of heavier involvement of military personnel and munitions factories in undercover dealings. Most black market transactions occurred in the last years of the war and immediately after the war; in particular, a substantial portion of the national income leaked into the black markets in 1945.

Viewed differently, the wartime pattern of the relative statistical discrepancies was driven by the fact that the revision of official prices lagged substantially behind changes in black market prices during the war. Equation (4) implies that statistical discrepancies widen when official prices $\left(P_{\text {final }}^{o m}\right.$ and $\left.P_{\text {inter }}^{o m}\right)$ are well below black market prices $\left(P_{\text {final }}^{b m}\right.$ and $\left.P_{\text {inter }}^{b m}\right)$. According to Table 2 , the wholesale/retail price indexes as a proxy for the official prices tended to be low relative to the GNE

25 Miwa (2015) reports the cases of inefficient rationing, which was induced by the Material Mobilization Plans. According to USSBS (1947), the Japanese government was never able to establish an efficient over-all control of rationing and prices, and to crack down effectively on illegal transactions in comparison with the U.S. Office of Price Administration. 
deflators, which partly reflected the black market prices from 1937 to 1945 . For example, the retail price index was 103\% of the GNE deflator in 1937 but was only $41 \%$ in 1945 .

In the postwar period, on the other hand, the statistical discrepancy ratio was quite high or $19.4 \%$ in 1946 , after which it gradually decreased but still remained high. The ratio was $14.6 \%$ in 1947 and $13.3 \%$ in 1948. For the years 1946 to 1948, the official prices still failed to catch up with the black market prices. As shown in Table 2, for example, the retail price index was only $43 \%$ of the GNE deflator in $1946,47 \%$ in 1947 , and $78 \%$ in 1948. In 1949 , the discrepancy ratio of $5.9 \%$ was not negligible, but not high compared with previous years. By the early 1950s, the government had removed most economic controls, and the black markets consequently disappeared. According to Table 2, the wholesale/retail price indexes were quite close to the GNE deflator in 1950.

Figure 4 depicts the relative magnitude of the financial surpluses, defined as net savings minus net investment, by the public and private sectors separately. A sharp contrast in financial surpluses between the wartime and the postwar periods is observed in this figure. During the war, on the one hand, the private sector had financial surpluses thanks mainly to forced savings and subsidies from the government, while the public sector had enormous financial deficits because of low tax revenues and large-scale fiscal expenditures including subsidies to the private sector. In the aftermath, on the other hand, the public sector generated financial surpluses except in 1946 thanks mainly to improving tax revenues, while the private sector carried large financial deficits despite subsidies from the government. Throughout the two periods, however, the continuation of largely positive statistical discrepancies implies that a financial surplus of one sector could not cover a financial deficit of the other.

\subsection{GNE and GNI deflators and official prices}

Let us next examine the behavior of the GNE and GNI deflators together with the official prices that were recorded in the wholesale/retail price indexes. All deflators and price indexes were standardized using the base years 1934-1936. As equations (5) and (6) imply, the official prices should be between the GNE and GNI deflators. As shown in Table 2 and Figure 5, however, the official prices were between both deflators only in 1939. For both the wholesale and retail prices, the official prices were above the GNE deflators in 1937 and 1938, and below the GNI deflators for 
the years 1940-1949.

There are three possible reasons for the deviation of the two deflators from the theoretical prediction. First, the two deflators and the official price indexes differed substantially in the coverages and weights of the commodity baskets in particular for the wartime data. As mentioned in Section 2.1, the two deflators were based on the Morita indexes, which were constructed in quite an ad hoc manner without taking any simple or weighted average of commodity baskets. However, the official price indexes were computed as a simple average of official prices for a certain commodity basket.

Second, the Morita indexes might have failed to capture precise information about black market prices, and those prices were inferred to be too low from the indexes. According to equations (5) and (6), the GNE deflator is underestimated if the black market prices of final goods $\left(P_{\text {final }}^{b m}\right)$ are too low, while the GNI deflator is overestimated if the black market prices of intermediate goods $\left(P_{\text {inter }}^{\text {bm }}\right)$ are too low.

Third, the GNI deflator was estimated to be too high for the following reason. The real share of intermediate goods procured from black markets $\left(\frac{V_{\text {inter }}^{\text {bm }}}{V_{\text {final }}^{\text {om }}+V_{\text {final }}^{b m}}\right)$ would have been underestimated if firms had been reluctant to report transactions with illegal dealers in filing corporate tax returns. According to equation (6), the GNI deflator is too high if $\frac{V_{\text {inter }}^{b m}}{V_{\text {final }}^{\text {om }}+V_{\text {final }}^{\text {bm }}}$ is too low. Given the last two reasons, the statistical discrepancies reported by the EPA (1964) offer a lower bound for the size of the income leakages into the black markets.

In the light of the above inconsistency between the GNE/GNI deflators and the official price indexes (wholesale/retail price indexes), equation (7) cannot be employed for deriving the real share of black markets $\left(\frac{V_{\text {inter }}^{b m}+V_{\text {final }}^{b m}}{V_{\text {final }}^{\text {om }}+V_{\text {final }}^{b m}}\right)$. Thus, the share is approximated under the assumption that $P^{o m} \approx \frac{P^{G N E}+P^{G N I}}{2}$. The black-to-official market price ratios $\left(\frac{P^{b m}}{P^{o m}}\right)$ are available from the Bank of Japan (1966) for the postwar period between 1946 and 1951.

As reported in Table 3, the real share of black markets ranged between $2.4 \%$ and $8.7 \%$ in the 
years 1946 to 1950 . Given that the black-to-official market price ratio is close to one, the ratio of 29.1\% in 1951 is meaningless. As mentioned above, the EPA national accounts are likely to underestimate the scale of the income leakage into the black markets. Thus, the real share of the black markets reported in Table 3 should be interpreted as its lower bound.

\subsection{Marshallian $\mathrm{k}$ and money demand from the black markets}

\subsubsection{Marshallian $\mathrm{k}$ deviating from its long-run average}

As pointed out in the introduction, Marshallian k, defined as the outstanding BoJ notes over nominal GNE, started to deviate from its long-run average of $10 \%$ in 1937, peaking at around 50\% in 1945 and reverting quickly to $10 \%$ by 1949 (see Figure 1). More concretely, in the years 1937 to 1945, the outstanding BoJ notes on issue increased by a factor of 24.1 times, while nominal GNE increased by only 4.9 times. Accordingly, Marshallian k rose from 9.8\% to 48.4\%. In the years 1945 to 1949, however, nominal GNE increased by 29.5 times, whereas the outstanding BoJ notes on issue increased by only 6.4 times. As a result, Marshallian k decreased from $48.4 \%$ to $10.5 \%$.

As discussed descriptively in Section 2.4 and analytically in Section 3.2, there is a possibility that the national income leaking out of the formal economy created strong demand for BoJ notes from the black marketers who received the leaked income. In other words, the circulation of BoJ notes encourage the leaked income to flow back to the treasury as large seigniorage revenues. Then, this strong money demand from the black markets caused an upward deviation of Marshallian k from its long-run average.

As emphasized above, the national income continued to leak out of the formal economy into the black markets throughout the controlled period 1937-1949. However, Marshallian k deviated substantially from its long-run average of $10 \%$ during the war but reverted quickly to $10 \%$ in its aftermath. It follows that the black marketers made a considerable investment in BoJ notes in the former period 1937-1945, but they shifted their portfolios from BoJ notes to physical assets in the latter period 1945-1949. We next examine this possibility quantitatively.

Equation (14) allows us to allocate an increment in aggregate money supply $\left(M_{n, t}^{s}-M_{n, t-1}^{s}\right)$ between additional money demand from the formal economy $\left(M_{n, t}^{F}-M_{n, t-1}^{F}\right)$ and from the black markets $\left(M_{n, t}^{B}-M_{n, t-1}^{B}\right)$. The former demand was driven mainly by transactions, and it is assumed 
to be proportional to nominal GNE at the constant of $m$. Then, $M_{n, t}^{F}-M_{n, t-1}^{F}$ is replaced by $m\left(Y_{n, t}^{E}-Y_{n, t-1}^{E}\right)$, where $m$ is assumed to be 0.1 as the long-run average of Marshallian k.

Table 4 reports the magnitude (relative to nominal GNE) of additional money demand from the formal economy (column (a)) and from the black markets (column (b)). Additional money demand from the formal economy hovered at around 1.5\% of nominal GNE up to 1944, but it expanded with nominal GNE after the war; it was $7.6 \%$ of nominal GNE in 1946, 6.4\% in 1947, and $5.1 \%$ in 1948 . However, additional demand from the black markets was high in the final years of the war; it was $3.4 \%$ in $1943,8.6 \%$ in 1944 , and $29.4 \%$ in 1945 . However, it was only in 1947 that the black marketers expanded their money holding during the postwar period. The negative number reported in year $1949(-2.1 \%)$ suggests that the black marketers reduced their cash holdings at the very end of the controlled-economy period. While large quantities of BoJ notes were issued even after the war, the new notes were held for transaction purposes by those in the formal economy and no longer as a financial instrument by those in the black markets.

According to equation (15), strong additional demand for BoJ notes from the black markets contributed to the upward deviation of Marshallian k. During the war, particularly in 1943, 1944, and 1945, stronger money demand from the black markets indeed made Marshallian k increase above its long-run average of $10 \%$. After the war, however, this strong demand disappeared except in 1947. Instead, high nominal economic growth (measured in $\frac{Y_{n, t}^{E}-Y_{n, t-1}^{E}}{Y_{n, t}^{E}}$ ) and previously high Marshallian k $\left(\frac{M_{n, t-1}^{S}}{Y_{n, t-1}^{E}}-m>0\right)$ contributed jointly to a steep decline in Marshallian k.

\subsubsection{Black marketers' portfolios during and after the war}

The above findings imply that after the war, the black marketers allocated more of their portfolios to physical assets-such as durables, inventories, and even old houses obtained through barter transactions-than to BoJ notes received through cash transactions. Equation (13) allows us to separate an investment in such physical assets $\left(B T_{n, t}\right)$ from an investment in BoJ notes $\left(M_{n, t}^{B}-M_{n, t-1}^{B}\right)$. Then, it is possible to examine the extent to which the leaked income, measured as the statistical discrepancy $\left(S D_{n, t}\right)$, returned to the formal economy through cash transactions in 
the black markets by $\frac{M_{n, t}^{B}-M_{n, t-1}^{B}}{S D_{n, t}}$.

As shown in Figure 6, less than one fourth of the leaked income flew back to the formal economy (more precisely to the treasury) in the years 1937 to 1942 . By issuing BoJ notes to the black markets, however, the government refinanced $37.6 \%$ of the leaked income in 1943, and $78.8 \%$ in 1944 respectively. Given that additional money demand from the black markets amounted to $29.4 \%$ of nominal GNE in $1945,{ }^{26}$ quite a large portion of the leaked income was expected to return to the formal economy through illicit cash transactions. After the war, however, the black marketers did not add BoJ notes to their portfolios except in 1947. In 1949, they even disposed of cash on hand, equivalent to $35.5 \%$ of the leaked income, thereby switching their portfolios completely to physical assets.

A major reason for this shift from BoJ notes to physical assets after the war is that the black marketers were extremely reluctant to hold BoJ notes in response to the postwar galloping inflations. ${ }^{27}$ In terms of the GNE deflator, the annual inflation rate ranged between $10 \%$ and $20 \%$ during the war, but it jumped to $103 \%$ in 1945 , $483 \%$ in $1946,150 \%$ in 1947 , and $75 \%$ in 1948 . In turn, the reluctance of the black marketers to hold BoJ notes reduced aggregate money demand, thereby further increasing the high inflation rates.

Table 5 reports the portfolios held by the black marketers in real terms. It computes real money balances in column (4) $\left(\frac{1}{P_{t}^{G N E}} \sum_{\tau=1937}^{t}\left(M_{n, \tau}^{B}-M_{n, \tau-1}^{B}\right)\right)$, real physical assets in column (6) $\left(\sum_{\tau=1937}^{t} \frac{B T_{n, \tau}}{P_{\tau}^{G N E}}\right)$, total wealth in column $(7)$, and the ratio of real money balances to total wealth in column (8). Here, a nominal value is converted to a real value by the GNE deflator $\left(P_{t}^{G N E}\right)$ with 1934-1936 as the base years. Because of the absence of data, the black marketers were assumed to add no physical assets to their portfolio in 1945 . In addition, real physical assets held by the black marketers were assumed not to be depreciated over time.

${ }_{26}$ As described in Section 4.2, additional money demand from the black markets is equivalent to the minimum value of the statistical discrepancy by construction.

27 In addition, the black marketer's shift from BoJ notes to physical assets might have been driven by the intention to switch from old bills to new bills, which was hinted at by the government in late 1945, as described in Section 2.4.2. 
What is surprising is that real money balances increased to 5.9 billion yen in 1945 but declined almost to zero in 1949 . However, real physical assets grew continuously from 13.9 billion yen in 1946 to 18.3 billion yen in 1949 even after the war. Accordingly, the ratio of BoJ notes to total wealth peaked at $33.1 \%$ in 1945 and declined to zero in 1949. The black marketers accumulated wealth rapidly including BoJ notes during the war; however, they dramatically shifted their holdings away from BoJ notes to physical assets immediately after the war.

The total wealth held by the black marketers, reported in column (7) in Table 5, almost equaled the real size of the national economy (real GNE) by the end of the war and continued to grow until the controlled economy ended in the early 1950s. For example, the total wealth of the black marketers was equal to $72.5 \%$ of real GNE in 1944 , and $126.8 \%$ in 1949 . These findings suggest that the black market transactions helped to transfer physical resources such as durables, inventories, and housing assets from the wartime activities and even from postwar reconstructions to the post-control economy, which finally began to grow after the economic controls imposed by the government and the import restrictions by the General Headquarters were all lifted by the early $1950 \mathrm{~s} .{ }^{28}$

\section{Conclusion}

This paper provides two important lessons. First, the circulation of central bank notes is closely related to the emergence of black market transactions, but there is by no means a one-toone correspondence between the two. In the heavily controlled Japanese economy from 1937 to 1949, a substantial portion of the national income leaked out of the formal economy and into the black markets, and the black marketers accumulated enormous amounts of wealth throughout the period. However, BoJ notes were a major financial instrument among the black marketers only in the final years of the war. While large quantities of BoJ notes were issued even after the war, the new notes were held for transaction purposes by those in the formal economy, not as a financial instrument by those in the black markets, who made a dramatic shift from BoJ notes to physical

28 As reported in Mizoguchi and Nojima (1993), real GDP peaked at 7.7 trillion yen (1955 constant prices) in 1942 during the war, while it exceeded 7 trillion yen in 1952 and reached 8.3 trillion yen in 1955. 
assets in their portfolios. In the postwar period, declining money demand from the black markets contributed to the acceleration of inflations.

Second, high tension between efficiency and inequality is brought by illegal transactions in an inefficient economy, which is first pointed out by Leff (1964). ${ }^{29}$ Given a heavily controlled economy such as the wartime and postwar Japanese economy, illegal transactions may be interpreted as a second-best response to heavy economic controls. In the final years of the war, for example, illegal cash transactions helped to return the leaked income to the financially deficient treasury in the form of large seigniorage revenues. After the war, however, illegal barter transactions helped physical resources such as durables and inventories to escape from inefficient uses in the controlled economy into efficient uses in the post-control market economy, which finally began to grow after most economic controls were lifted in the early 1950s.

What is obvious here is that any resource allocation through illegal transactions, either cash or barter, cannot be considered unconditionally as a fair allocation device. Only after a government confiscates financial and physical resources accumulated in black markets, and redistributes them equally among those in the formal economy, can illegal transactions in a controlled economy be justified in the long run. In this light, the Emergency Financial Measure announced by the Japanese government in February 1946, which included forcing the deposit of old BoJ bills and imposing extremely high capital levies on frozen deposits as explained in Section 2.4.2, may be interpreted as one example of such an efficient-as well as fair-policy scheme. Following the introduction of this measure, however, concealed cash assets were confiscated by the government, but illicit physical assets were still held among the black marketers. Thus, the above measure remained imperfect given that the black marketers shifted their portfolio holdings from BoJ notes to physical assets after the war.

${ }^{29}$ Leff (1964) presents a case in which bureaucratic corruption, often involving illegal transactions, may make a military-oriented government business-friendlier, but created vested interests among those in a ruling class, whose elimination requires a new center of power outside the bureaucracy. Interpreting the Japanese experience along Leff (1964), the wartime and postwar black market transactions helped to reallocate at least partially scarce resources from military purposes to civilian purposes, whereas their adverse effects were eliminated, though not entirely, by the postwar democratization promoted by the new government and the occupation forces. 


\section{References:}

Adams, F. G., and P. E. de Janosi, 1966, "On the statistical discrepancy in the revised U.S. national accounts," Journal of the American Statistical Association, vol. 61 (316), pp. 1219-1229.

Bank of Japan, Statistics Bureau, 1966, Major Statistics of the Japanese Economy from the Meiji Era, Tokyo: Bank of Japan, Statistics Bureau. (in Japanese)

Bhattacharyya, D. K., 1990, “An econometric method of estimating the 'hidden economy', United Kingdom (1960-1984): Estimates and tests,” The Economic Journal, vol. 100 (September), pp. $703-717$.

Cagan, P., 1956, "The monetary dynamics of hyperinflation," in M. Friedman, ed., Studies in the Quantity Theory of Money, Chicago: University of Chicago Press, pp. 25-117.

Cagan, P., 1958, “The demand for currency relative to the total money supply," Journal of Political Economy, vol. 66 (4), pp. 302-328.

Economic Planning Agency, 1964, The Japanese National Accounts for the 1962 Fiscal Year, Tokyo: National Printing Bureau. (in Japanese)

Feige, E. L., 1989, "The meaning and measurement of the underground economy," in Feige, E. L., ed., The Underground Economy: Tax Evasion and Information Distortion, Cambridge and New York: Cambridge University Press, pp. 13-56.

Frey, Bruno S. and Werner W. Pommerehne, 1982, "Measuring the hidden economy: Though this be madness, there is method in it," Tanzi, Vito, ed., The Underground Economy in the United States and Abroad, Lexington, MA: Heath, pp. 3-27.

Fujiwara, H., and Y. Ogawa, 2016, "Estimating Japan's gross domestic income based on taxation data," Bank of Japan Working Paper Series, No. 16-E-20.

Fukao, Kyoji, Jean-Pascal Bassino, Tatsuji Makino, Ralph Paprzycki, Tokihiko Settsu, Masanori Takashima, and Joji Tokui, 2015, Regional Inequality and Industrial Structure in Japan: 18742008, Tokyo: Maruzen.

Gartaganis, J. and S. Goldberger, 1955, "A note on the statistical discrepancy in the national accounts," Econometrica, vol. 23 (2), pp. 166-173.

Georgiou, George M., 2011, "Measuring the size of the informal economy: A critical review,” Journal of Interdisciplinary Economics, vol. 23 (1), pp. 85-107. 
Gutmann, P. M., 1977, “The subterranean economy,” Financial Analyst Journal, vol. 33 (6), pp. 2628.

Hara, A., 1976, "The economic structure of "The Greater East Asia Co-Prosperity Sphere," Tochi Seidoshi gaku, vol. 18 (3), pp. 1-28. (in Japanese)

Hattori, T., and K. Oguro, 2016, "An endeavor to estimate seigniorage before the end of and immediately after the Pacific War," Journal of the Japanese and International Economies, vol. $41,1-16$.

Jean-Pascal, B., K. Fukao, and T. Settsu, 2016, "Productivity growth in Meiji Japan: The structural and regional dynamics," presented at Asian Historical Economics Conference 2016, Seoul, 2-3 September 2016.

Kikuchi, K., 1947, "A study on the causes of the defeat from the judiciary point of view," Shiho Kenkyu, Report 34-5. (in Japanese)

Leff, N. H., 1964, "Economic development through bureaucratic corruption," The American Behavioral Scientist, vol. 8 (3), pp. 8-14.

Ministry of Finance, Editorial Office of History of Finance in Showa Era, 1986, History of Public Finance in Showa Era, XII, Financial Markets 1, Tokyo: Toyo Keizai Shinpo-sha. (in Japanese)

Miwa, Y., 2015, Japan’s Economic Planning and Mobilization in Wartime, 1930s-1940s, New York: Cambridge University Press.

Miwa, Y., and J. M. Ramseyer, 2004, "The effectiveness of economic controls: The myth of the priority-production-scheme,” Keizaigaku ronshu, vol. 70 (2), pp. 60-119. (in Japanese)

Mizoguchi, T., and N. Nojima, 1993, "Nominal and Real GDP of Japan: 1940-1945," Journal of the Japan Statistical Society, vol. 23 (1), pp 91-107. (in Japanese)

Mizoguchi, T., 1995, “On some surveys on black market of the World War II period," Institute of Economic Research, Hitotsubashi University, Discussion Paper Series B, No. 16. (in Japanese) Mizoguchi, T., 1996, The Japanese Economy of the 1940s in the long-term system of the national account," Keizai Kenkyu, vol. 47 (2), pp. 97-108. (in Japanese)

Morita, Y. (ed.), 1963, On Prices, Tokyo: Shunjyu-sha. (in Japanese)

Nakamura, T., 1974, On the Japanese Controlled Economy, Tokyo: Nihon Keizai Shimbun-sha. (in Japanese) 
Nakamura, T., 1983, Economic Growth in Prewar Japan, New Haven and London: Yale University Press.

Nishida, Y., 1994, "People's life conditions in time of the War: Attributes of wartime black markets," in Oishi, ed., 1994, History of the Japanese Imperialism III: The World War II Period, Tokyo: University of Tokyo Press. (in Japanese)

O’Higgins, Michael, 1989, “Assessing the underground economy in the United Kingdom," in Feige, E. L., ed., The Underground Economy: Tax Evasion and Information Distortion, Cambridge and New York: Cambridge University Press, pp. 175-195.

Ohkawa, K., N. Takamatsu, and Y. Yamamoto, 1974, Long-Term Economic Statistics of Japan: National Income, Tokyo: Toyo Keizai Shinpo-sha. (in Japanese)

Ono, H., 2007, "The foundation of the wartime housing policy and the transformation of housing markets,” Rikkyo Keizaigaku Kenkyu, vol. 60 (3), pp. 201-226. (in Japanese)

Rockoff, Hugh, 1984, Drastic Measures: A History of Wage and Price Controls in the United States, Cambridge and New York: Cambridge University Press.

Rogoff, S. R., 2016, The Curse of Cash, New Jersey: Princeton University Press.

Saito, M., 2017, “On wartime money finance in the Japanese occupied territories during the Pacific War: The case of instant reserve banks as bad central banks," Graduate School of Economics, Hitotsubashi University, Discussion Paper No. 2017-03.

Schneider, Friedrich, 2005, "Shadow economies around the world: What do we really know?" European Journal of Political Economy, vol. 21, pp. 598-642.

Shibamoto, M. and M. Shizume, 2014, "Exchange rate adjustment, monetary policy and fiscal stimulus in Japan's escape from the Great Depression,” Explorations in Economic History, 53, pp. $1-18$.

Shima, K., 1983, "On the fiscal policy by Korekiyo Takahashi," Monetary and Economic Studies, vol. 2 (2), pp. 83-124. (in Japanese)

Tanzi, Vito, 1999, "Uses and abuses of estimates of the underground economy," The Economic Journal, 109 (June), pp. 338-347.

Thomas, Jim, 1999, "Quantifying the black economy: 'Measurement without theory' yet again?" The Economic Journal, 109 (June), pp. 381-389. 
The United States Strategic Bombing Survey (USSBS), 1946, "The effects of strategic bombing on Japan's war economy," in Final Reports of the United States Strategic Bombing Survey, No. 53, U.S. Government Printing Office.

The United States Strategic Bombing Survey (USSBS), 1947, "The Japanese wartime standard of living and utilization of manpower," in Final Reports of the United States Strategic Bombing Survey, No. 42, U.S. Government Printing Office.

Williams, Faith M., 1945, "Price control and rationing in foreign countries during the War," Monthly Labor Review, vol. 61 (5), pp. 882-899.

Yamamoto, R, 2011, "On estimation methods of aggregate income in the system of national accounts: A cross-country comparison," Kikan Kokumin Keizai Keisan, No. 146, pp. 53-72. (in Japanese) 
Table 1: Comparison with the Morita index (standardized as of 1936)

\begin{tabular}{|c|c|c|c|c|c|c|c|c|}
\hline & \multicolumn{2}{|c|}{$\mathrm{BoJ}$} & \multicolumn{4}{|c|}{ Morita index } & \multirow{2}{*}{\multicolumn{2}{|c|}{$\frac{\text { EPA }}{\text { (5) GNE deflator }}$}} \\
\hline & \multicolumn{2}{|c|}{ official price } & \multicolumn{2}{|c|}{$\begin{array}{c}\text { (3) effective } \\
\text { wholesale price }\end{array}$} & \multicolumn{2}{|c|}{$\begin{array}{c}\text { (4) effective retail } \\
\text { price }\end{array}$} & & \\
\hline & (1) wholesale & (2) retail & & $\begin{array}{l}\text { relative } \\
\text { to (1) }\end{array}$ & & $\begin{array}{c}\text { relative } \\
\text { to (2) }\end{array}$ & & $\begin{array}{l}\text { relative } \\
\text { to (1) }\end{array}$ \\
\hline 1936 & 100.0 & 100.0 & 100.0 & 1.00 & 100.0 & 1.00 & 100.0 & 1.00 \\
\hline 1937 & 121.4 & 109.4 & 118.9 & 0.98 & 108.6 & 0.99 & 105.8 & 0.87 \\
\hline 1938 & 128.1 & 125.3 & 125.7 & 0.98 & 120.3 & 0.96 & 117.3 & 0.92 \\
\hline 1939 & 141.5 & 140.4 & 145.4 & 1.03 & 134.8 & 0.96 & 144.2 & 1.02 \\
\hline 1940 & 158.4 & 163.1 & 170.7 & 1.08 & 175.0 & 1.07 & 183.7 & 1.16 \\
\hline 1941 & 169.7 & 165.0 & 184.2 & 1.09 & 204.1 & 1.24 & 206.7 & 1.22 \\
\hline 1942 & 184.6 & 169.8 & 235.9 & 1.28 & 265.6 & 1.56 & 251.0 & 1.36 \\
\hline 1943 & 197.5 & 180.2 & 266.5 & 1.35 & 312.3 & 1.73 & 291.3 & 1.48 \\
\hline 1944 & 223.8 & 201.7 & 325.0 & 1.45 & 390.0 & 1.93 & 355.8 & 1.59 \\
\hline
\end{tabular}

Sources: Bank of Japan (1966), and EPA (1964).

Table 2: Deflators, price indexes, and official discount rates (1934-1936 as base years)

\begin{tabular}{|c|c|c|c|c|c|c|c|}
\hline \multirow[b]{2}{*}{1930} & \multirow{2}{*}{\begin{tabular}{|r|} 
GNE deflator \\
1.03
\end{tabular}} & \multirow{2}{*}{\begin{tabular}{|r|} 
GNI deflator \\
1.02
\end{tabular}} & \multicolumn{2}{|c|}{$\begin{array}{l}\text { wholesale price index } \\
\text { (relative to GNE deflator } \\
\text { in parentheses) }\end{array}$} & \multicolumn{2}{|c|}{$\begin{array}{c}\text { retail price index (relative } \\
\text { to GNE deflator in a } \\
\text { parentheses) }\end{array}$} & \multirow{2}{*}{$\begin{array}{c}\text { official } \\
\text { discount } \\
\text { rate }\end{array}$} \\
\hline & & & 0.89 & $(86 \%)$ & 1.01 & $(98 \%)$ & \\
\hline 1931 & 0.90 & 0.89 & 0.75 & $(83 \%)$ & 0.89 & $(98 \%)$ & $5.4 \%$ \\
\hline 1932 & 0.93 & 0.95 & 0.83 & $(89 \%)$ & 0.89 & $(96 \%)$ & $5.3 \%$ \\
\hline 1933 & 0.98 & 1.01 & 0.95 & $(97 \%)$ & 0.95 & $(97 \%)$ & $4.0 \%$ \\
\hline 1934 & 0.97 & 0.96 & 0.97 & $(100 \%)$ & 0.97 & $(100 \%)$ & $3.7 \%$ \\
\hline 1935 & 1.01 & 1.03 & 0.99 & $(98 \%)$ & 0.99 & $(98 \%)$ & $3.7 \%$ \\
\hline 1936 & 1.04 & 1.07 & 1.04 & $(100 \%)$ & 1.04 & $(100 \%)$ & $3.4 \%$ \\
\hline 1937 & 1.10 & 1.03 & 1.26 & $(114 \%)$ & 1.14 & $(103 \%)$ & $3.3 \%$ \\
\hline 1938 & 1.22 & 1.08 & 1.33 & $(109 \%)$ & 1.30 & $(107 \%)$ & $3.3 \%$ \\
\hline 1939 & 1.50 & 1.35 & 1.47 & $(98 \%)$ & 1.46 & $(97 \%)$ & $3.3 \%$ \\
\hline 1940 & 1.91 & 1.77 & 1.64 & $(86 \%)$ & 1.70 & $(89 \%)$ & $3.3 \%$ \\
\hline 1941 & 2.15 & 2.01 & 1.76 & $(82 \%)$ & 1.72 & $(80 \%)$ & $3.3 \%$ \\
\hline 1942 & 2.61 & 2.38 & 1.91 & $(73 \%)$ & 1.77 & $(68 \%)$ & $3.3 \%$ \\
\hline 1943 & 3.03 & 2.76 & 2.05 & $(68 \%)$ & 1.87 & $(62 \%)$ & $3.3 \%$ \\
\hline 1944 & 3.70 & 3.30 & 2.32 & $(63 \%)$ & 2.10 & $(57 \%)$ & $3.3 \%$ \\
\hline 1945 & 7.50 & & 3.50 & $(47 \%)$ & 3.08 & $(41 \%)$ & $3.3 \%$ \\
\hline 1946 & 43.70 & 35.24 & 16.27 & $(37 \%)$ & 18.93 & $(43 \%)$ & $3.4 \%$ \\
\hline 1947 & 109.40 & 93.44 & 48.15 & $(44 \%)$ & 50.99 & $(47 \%)$ & $3.7 \%$ \\
\hline 1948 & 191.40 & 165.98 & 127.90 & $(67 \%)$ & 149.60 & $(78 \%)$ & $4.5 \%$ \\
\hline 1949 & 233.30 & 219.48 & 208.80 & $(89 \%)$ & 243.40 & $(104 \%)$ & $5.1 \%$ \\
\hline 1950 & 243.00 & 241.83 & 246.80 & $(102 \%)$ & 238.10 & $(98 \%)$ & $5.1 \%$ \\
\hline 1951 & 295.30 & 286.83 & 342.50 & $(116 \%)$ & 309.50 & $(105 \%)$ & $5.3 \%$ \\
\hline
\end{tabular}

Sources: Bank of Japan (1966), and EPA (1964).

Note (1): The computation of the 1945 GNE deflator is described in Section 4.2. 
Table 3: Real share of black markets for the postwar period

\begin{tabular}{|r|r|r|}
\cline { 2 - 3 } \multicolumn{1}{c|}{} & $\begin{array}{c}\text { black-to- } \\
\text { official ratio }\end{array}$ & $\begin{array}{c}\text { real black } \\
\text { market } \\
\text { share }\end{array}$ \\
\hline 1946 & 7.2 & $3.5 \%$ \\
1947 & 5.3 & $3.7 \%$ \\
1948 & 2.9 & $7.5 \%$ \\
1949 & 1.7 & $8.7 \%$ \\
1950 & 1.2 & $2.4 \%$ \\
1951 & 1.1 & $29.1 \%$ \\
\hline
\end{tabular}

Sources: Bank of Japan (1966).

Note (1): The real share is computed according to equation (7) under the assumption described in Section 4.4 .

Table 4: Marshallian $\mathrm{k}$ and money demand from the black markets

\begin{tabular}{|c|c|c|c|c|c|}
\hline & \multirow{2}{*}{ Marshallian $\mathrm{k}$} & \multirow{2}{*}{$\begin{array}{c}\text { change in } \\
\text { Marshallian } \mathrm{k}\end{array}$} & \multicolumn{2}{|c|}{$\begin{array}{c}\text { additional money } \\
\text { demand/nominal GNE }\end{array}$} & \multirow{2}{*}{$\begin{array}{l}\text { (c) nominal } \\
\text { GNE growth } \\
\text { index }\end{array}$} \\
\hline & & & \begin{tabular}{|l|} 
(a) from formal \\
economy
\end{tabular} & $\begin{array}{l}\text { (b) from black } \\
\text { markets }\end{array}$ & \\
\hline 1937 & $9.8 \%$ & $-0.6 \%$ & $2.4 \%$ & $-0.5 \%$ & $24.0 \%$ \\
\hline 1938 & $10.3 \%$ & $0.4 \%$ & $1.3 \%$ & $0.4 \%$ & $12.5 \%$ \\
\hline 1939 & $11.1 \%$ & $0.8 \%$ & $1.9 \%$ & $0.9 \%$ & $19.0 \%$ \\
\hline 1940 & $12.1 \%$ & $1.0 \%$ & $1.6 \%$ & $1.2 \%$ & $16.0 \%$ \\
\hline 1941 & $13.3 \%$ & $1.2 \%$ & $1.2 \%$ & $1.5 \%$ & $12.2 \%$ \\
\hline 1942 & $13.1 \%$ & $-0.2 \%$ & $1.7 \%$ & $0.4 \%$ & $17.4 \%$ \\
\hline 1943 & $16.1 \%$ & $2.9 \%$ & $1.5 \%$ & $3.4 \%$ & $14.8 \%$ \\
\hline 1944 & $23.8 \%$ & $7.7 \%$ & $1.4 \%$ & $8.6 \%$ & $14.3 \%$ \\
\hline 1945 & $48.4 \%$ & $24.6 \%$ & $3.5 \%$ & $29.4 \%$ & $34.9 \%$ \\
\hline 1946 & $19.7 \%$ & $-28.8 \%$ & $7.6 \%$ & $0.4 \%$ & $75.9 \%$ \\
\hline 1947 & $16.7 \%$ & $-2.9 \%$ & $6.4 \%$ & $3.2 \%$ & $63.7 \%$ \\
\hline 1948 & $13.3 \%$ & $-3.4 \%$ & $5.1 \%$ & $0.0 \%$ & $50.9 \%$ \\
\hline 1949 & $10.5 \%$ & $-2.8 \%$ & $2.1 \%$ & $-2.1 \%$ & $21.1 \%$ \\
\hline
\end{tabular}

Sources: Bank of Japan (1966), and EPA (1964).

Notes (1): Marshallian $\mathrm{k}$ is defined as the outstanding BoJ notes over nominal GNE.

(2): Additional money demand from the formal economy (normal transaction demand) is computed by $0.1\left(Y_{n, t}^{E}-Y_{n, t-1}^{E}\right)$ in equation (15).

(3): Additional money demand from the black markets $\left(M_{n, t}^{B}-M_{n, t-1}^{B}\right)$ is calculated by equation (14) with $m=0.1$.

(4): The nominal GNE growth index is defined as $\frac{Y_{n, t}^{E}-Y_{n, t-1}^{E}}{Y_{n, t}^{E}}$ in equation (15). 
Table 5: Black marketers' portfolios

(unit: million yen, 1934-1936 constant prices)

\begin{tabular}{|c|c|c|c|c|c|c|c|c|c|}
\hline \multirow[b]{2}{*}{1937} & \multirow{2}{*}{$\begin{array}{l}\text { (1) real GNE } \\
21,300\end{array}$} & \multirow{2}{*}{\begin{tabular}{|c}
$\begin{array}{c}\text { (2) statistical } \\
\text { discrepancy } \\
\text { (real) }\end{array}$ \\
1,450
\end{tabular}} & \multirow{2}{*}{\begin{tabular}{|c|}
$\begin{array}{c}\text { (3) additional } \\
\text { money } \\
\text { demand from } \\
\text { black markets } \\
\text { (nominal) }\end{array}$ \\
-124
\end{tabular}} & \multirow{2}{*}{\begin{tabular}{|r|}
$\begin{array}{c}\text { (4) real } \\
\text { money } \\
\text { balances in } \\
\text { black markets }\end{array}$ \\
-112
\end{tabular}} & \multirow{2}{*}{ 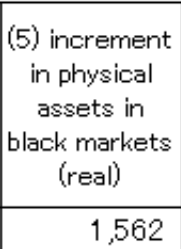 } & \multirow{2}{*}{$\begin{array}{r}\begin{array}{c}\text { (6) real } \\
\text { physical } \\
\text { assets in } \\
\text { black markets }\end{array} \\
1,562\end{array}$} & \multicolumn{2}{|c|}{$\begin{array}{l}\text { (7) outstanding black market } \\
\text { wealth (real, (4)+(6)), and the } \\
\text { ratio relative to real GNE } \\
((7) /(1))\end{array}$} & \multirow{2}{*}{$\begin{array}{l}\text { (8) share of } \\
\text { money } \\
\text { relative to } \\
\text { black market } \\
\text { wealth (real, } \\
(4) /(7)) \\
-7.8 \%\end{array}$} \\
\hline & & & & & & & 1,450 & $6.8 \%$ & \\
\hline 1938 & 21,959 & 2,589 & 114 & -8 & 2,496 & 4,058 & 4,050 & $18.4 \%$ & $-0.2 \%$ \\
\hline 1939 & 22,053 & 2,209 & 295 & 190 & 2,012 & 6,070 & 6,261 & $28.4 \%$ & $3.0 \%$ \\
\hline 1940 & 20,628 & 1,538 & 466 & 394 & 1,294 & 7,364 & 7,758 & $37.6 \%$ & $5.1 \%$ \\
\hline 1941 & 20,884 & 1,340 & 651 & 653 & 1,037 & 8,402 & 9,054 & $43.4 \%$ & $7.2 \%$ \\
\hline 1942 & 20,835 & 1,869 & 222 & 623 & 1,784 & 10,185 & 10,808 & $51.9 \%$ & $5.8 \%$ \\
\hline 1943 & 21,063 & 1,909 & 2,173 & 1,254 & 1,192 & 11,377 & 12,631 & $60.0 \%$ & $9.9 \%$ \\
\hline 1944 & 20,135 & 2,200 & 6,412 & 2,760 & 467 & 11,844 & 14,604 & $72.5 \%$ & $18.9 \%$ \\
\hline 1945 & 15,262 & 4,493 & 33,698 & 5,855 & & 11,844 & 17,699 & $116.0 \%$ & $33.1 \%$ \\
\hline 1946 & 10,870 & 2,105 & 1,904 & 1,048 & 2,062 & 13,906 & 14,954 & $137.6 \%$ & $7.0 \%$ \\
\hline 1947 & 11,965 & 1,746 & 42,344 & 806 & 1,359 & 15,265 & 16,071 & $134.3 \%$ & $5.0 \%$ \\
\hline 1948 & 13,924 & 1,850 & 538 & 463 & 1,847 & 17,112 & 17,575 & $126.2 \%$ & $2.6 \%$ \\
\hline 1949 & 14,471 & 857 & $-71,068$ & 76 & 1,162 & 18,274 & 18,349 & $126.8 \%$ & $0.4 \%$ \\
\hline
\end{tabular}

Sources: Bank of Japan (1966), and EPA (1964).

Notes (1): The computation of real GNE and the minimum statistical discrepancy for 1945 is described in Section 4.2 .

(2): It is assumed that the black marketers did not add any physical assets to their portfolios in 1945.

Column (2) is the nominal statistical discrepancy over the GNE deflator.

Column (3): Additional money demand from the black markets is computed using equation (14), or

$$
M_{n, t}^{B}-M_{n, t-1}^{B}=\left(M_{n, t}^{S}-M_{n, t-1}^{S}\right)-0.1\left(Y_{n, t}^{E}-Y_{n, t-1}^{E}\right) .
$$

Column (4): Real money balances are computed by

$$
\frac{1}{P_{t}^{G N E}} \sum_{\tau=1937}^{t}\left(M_{n, \tau}^{B}-M_{n, \tau-1}^{B}\right) \text {. }
$$

Column (5): Real barter transactions between formal and black markets are computed using equations (13) and (14), or

$$
\frac{B T_{n, t}}{P_{t}^{G N E}}=\frac{S D_{n, t}-\left[\left(M_{n, t}^{S}-M_{n, t-1}^{S}\right)-0.1\left(Y_{n, t}^{E}-Y_{n, t-1}^{E}\right)\right]}{P_{t}^{G N E}} .
$$

Column (6): The accumulation of real barter transactions is computed by $\sum_{\tau=1937}^{t} \frac{B T_{n, \tau}}{P_{\tau}^{G N E}}$.

Column (7) is the sum of columns (4) and (6).

Column (8) is the ratio of (4) to (7). 
Figure 1: Relative statistical discrepancy and Marshallian k

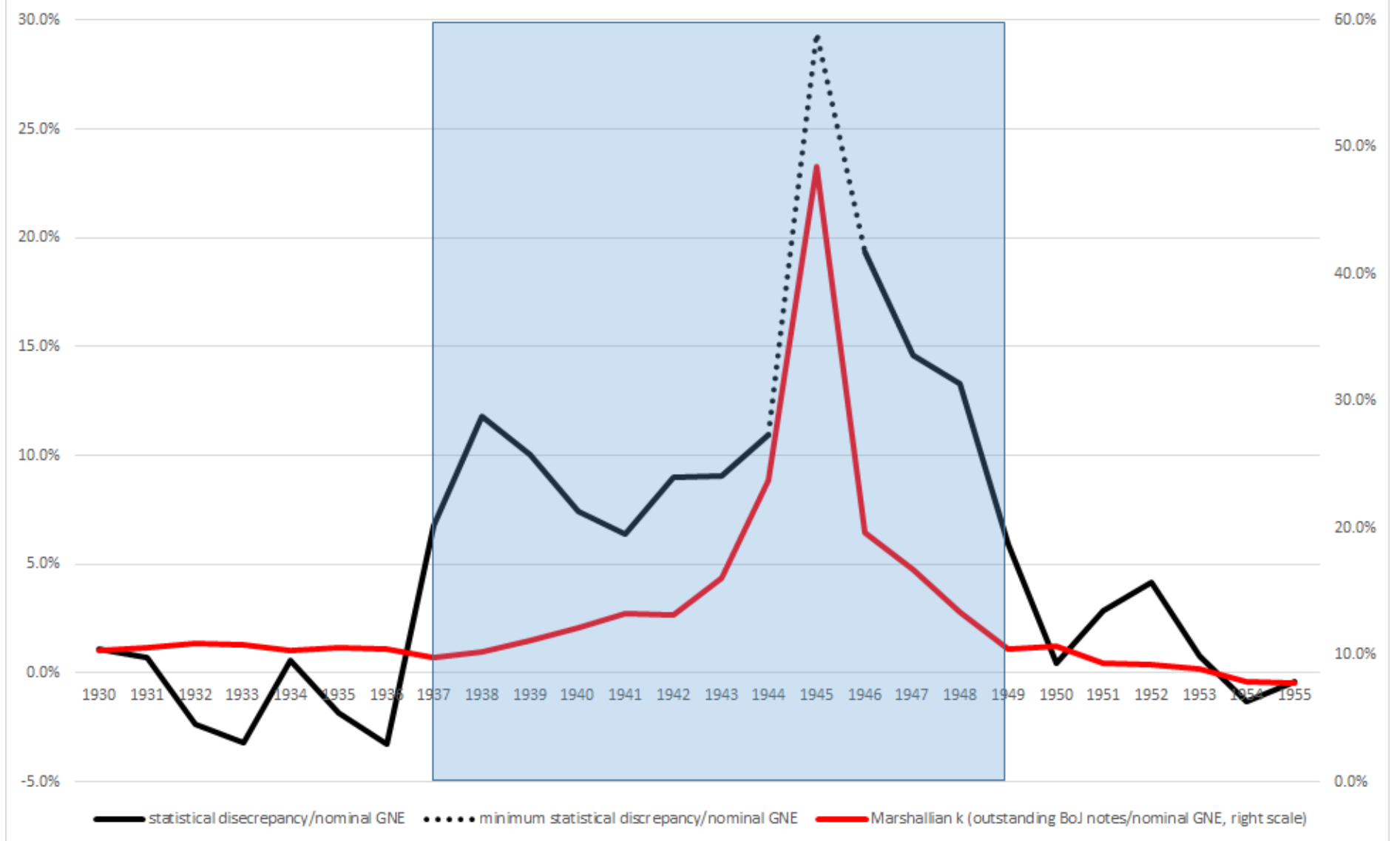

Sources: Bank of Japan (1966), and EPA (1964).

Notes (1) Marshallian $\mathrm{k}$ is defined as the outstanding BoJ notes over nominal GNE.

(2) The statistical discrepancy is defined as the difference between nominal aggregate expenditure and income.

(3): The computation of nominal GNE and the minimum statistical discrepancy for 1945 is described in Section 4.2 . 
Figure 2-1: Money issuance in a standard model

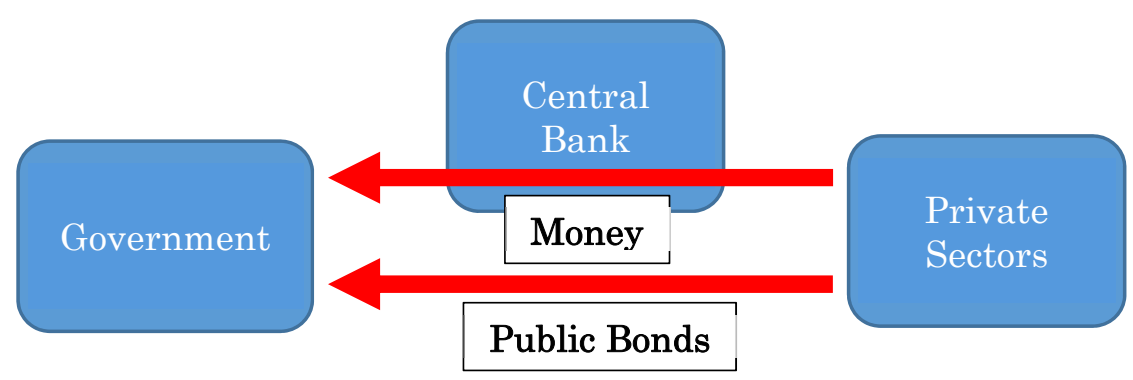

Figure 2-2: Money issuance in the presence of black markets

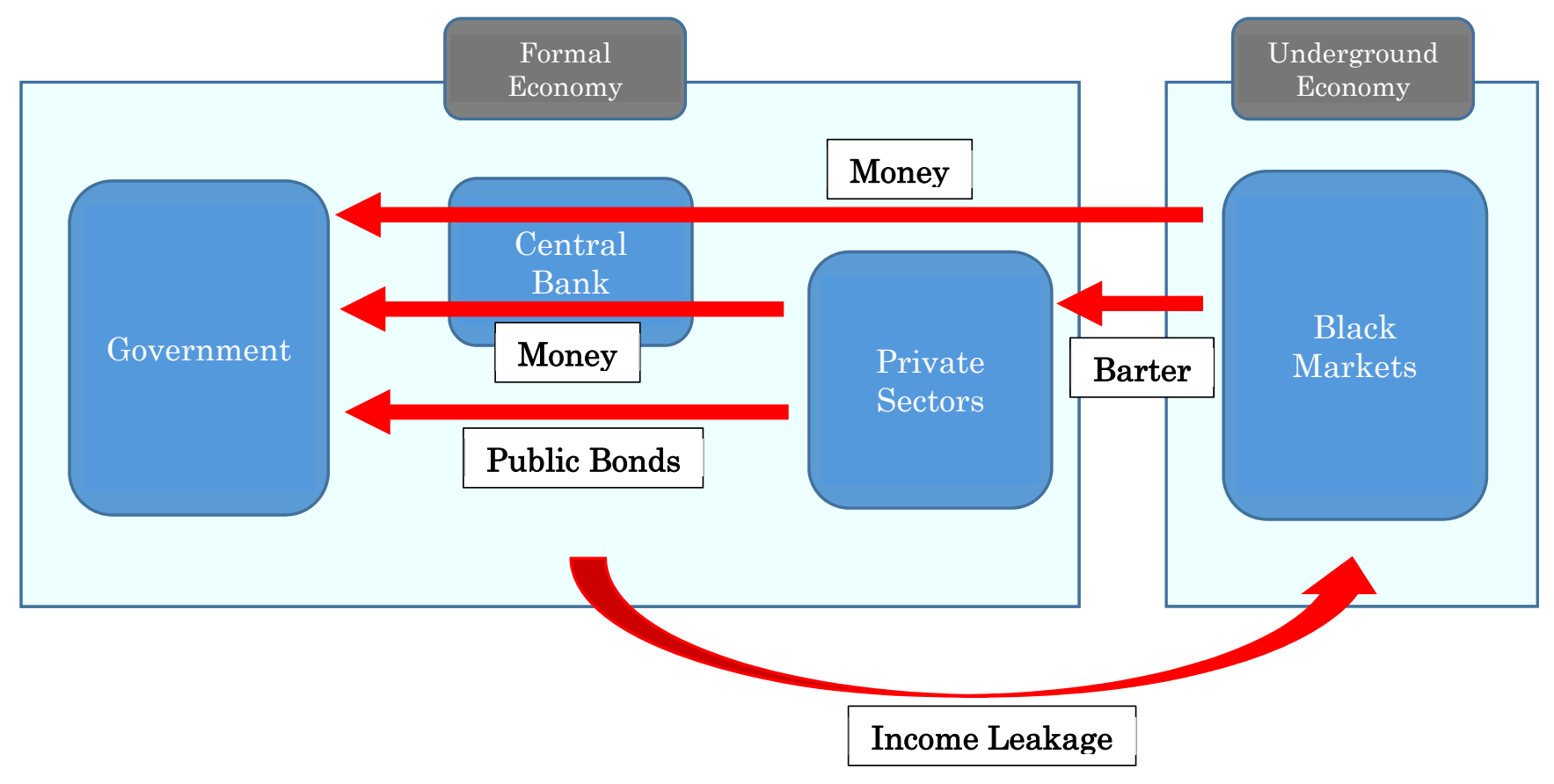


Figure 3: Net investment, net national saving, and statistical discrepancy

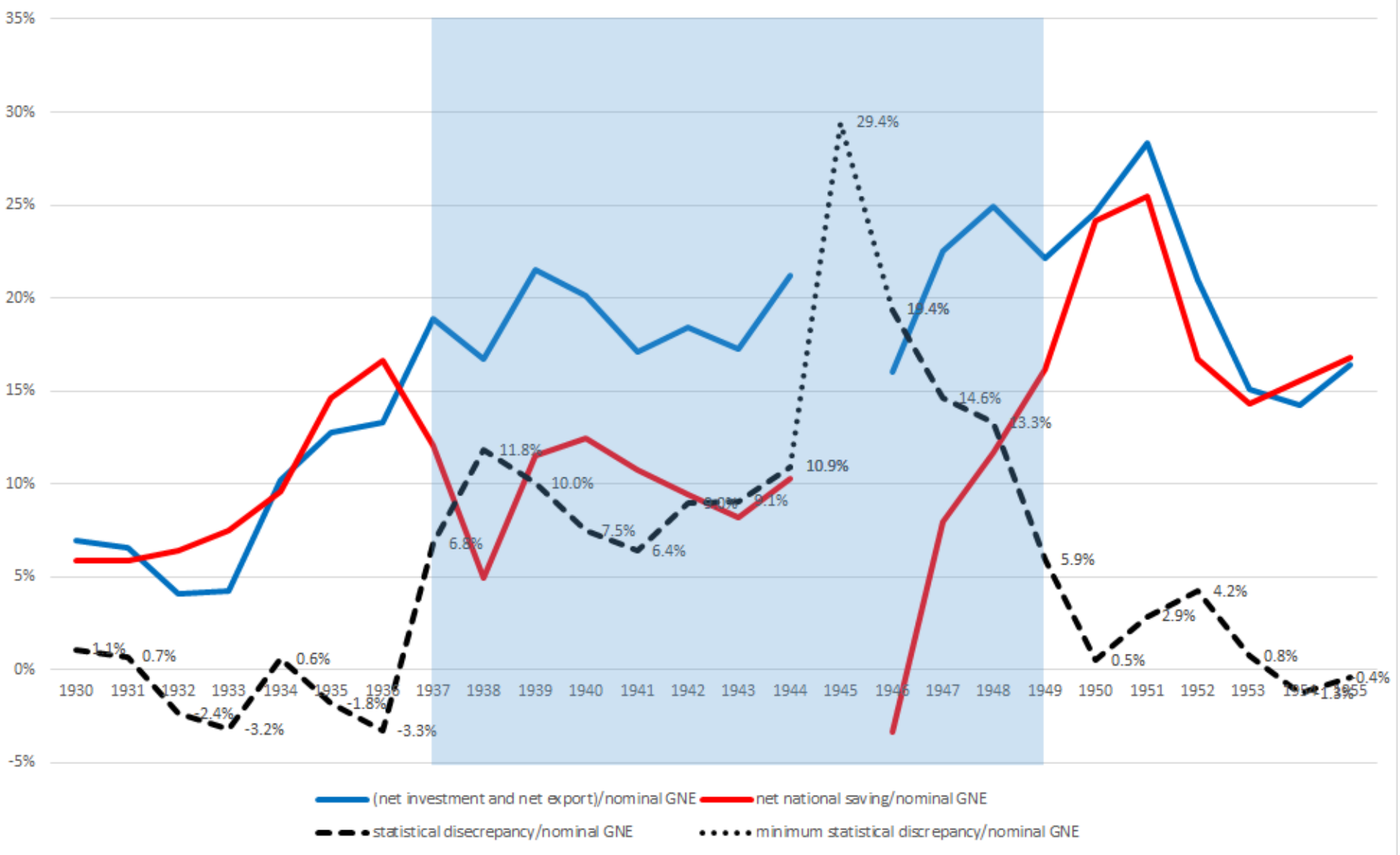

Sources: Bank of Japan (1966), and EPA (1964).

Notes (1): The computation of nominal GNE and the minimum statistical discrepancy for 1945 is described in Section 4.2 .

(2) Net investment is defined as the sum of net investment and current account balances, while net savings are defined as gross savings net of depreciation. 
Figure 4: Relative financial surplus in private and public sectors

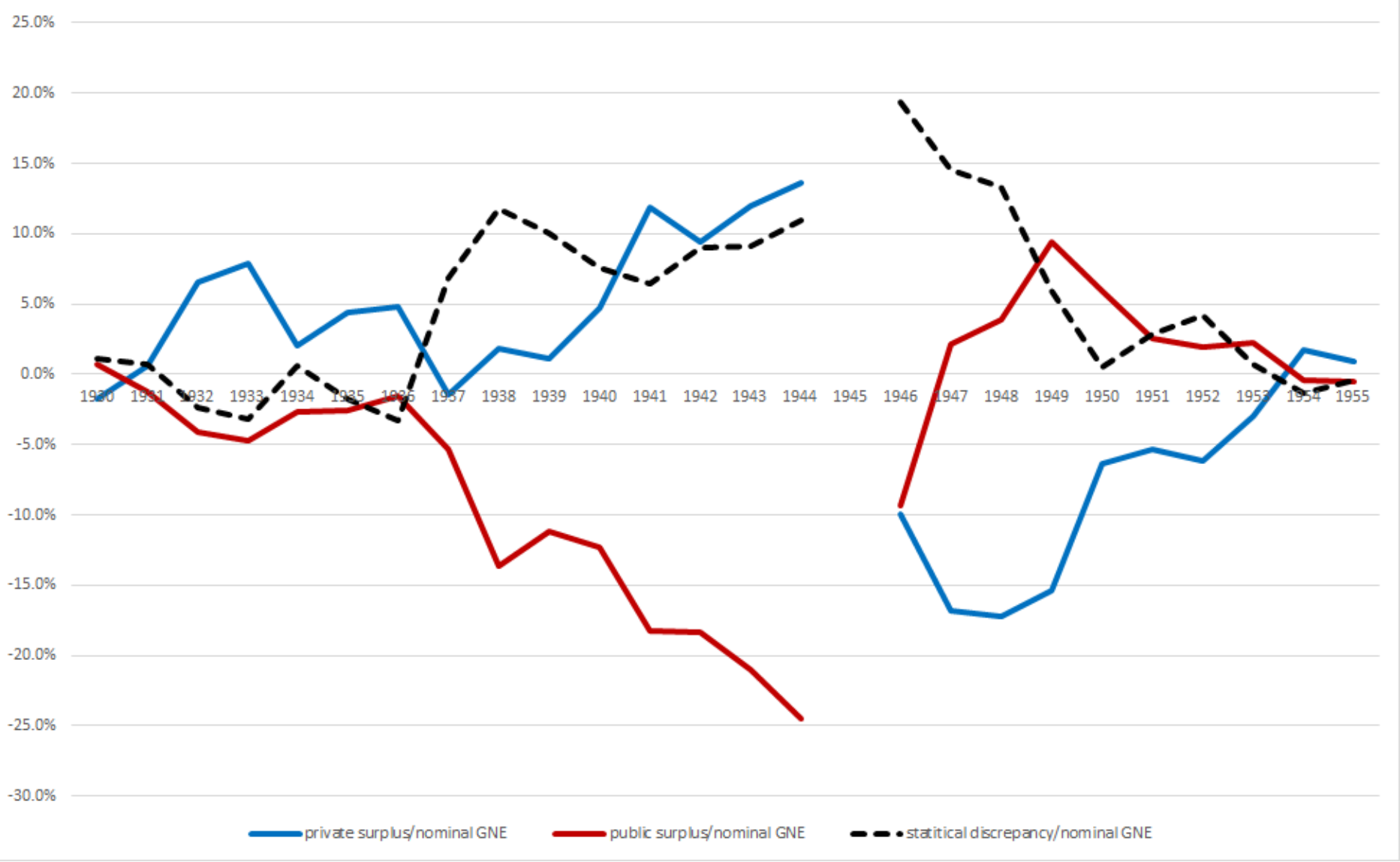

Sources: Bank of Japan (1966), and EPA (1964).

Notes (1): The private financial surplus is defined as (i) private net savings, minus (ii) private net investment including inventories and housing, minus (iii) current account balances.

(2): The public financial surplus is defined as (iv) public net savings, minus (v) public net investment including inventories. 
Figure 5: A comparison among GNE deflator, GNP deflator, and wholesale price index in logarithm (base years: 1934-1936)

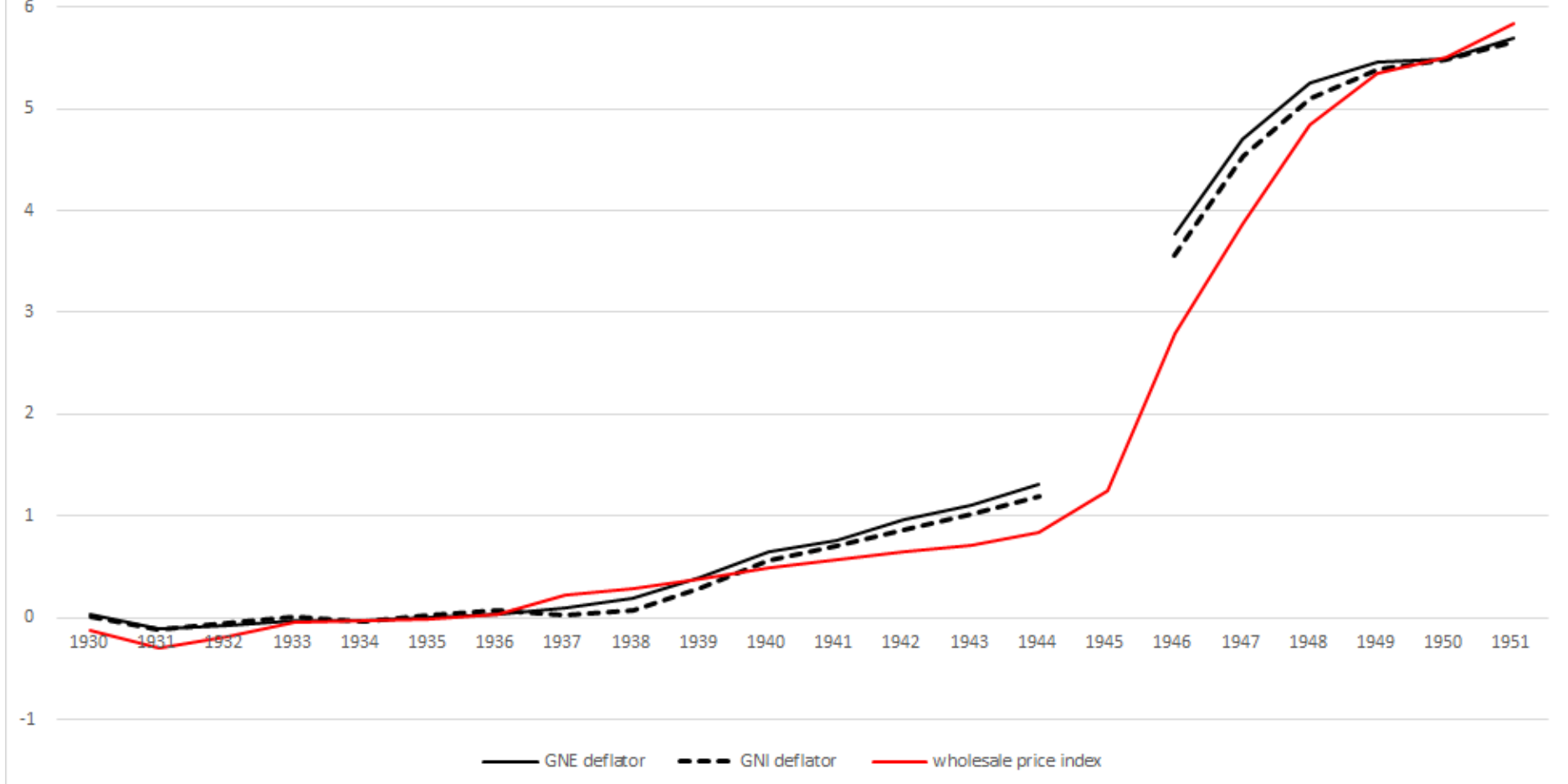

Sources: Bank of Japan (1966), and EPA (1964).

Note (1): The GNE and GNI deflators are computed using equations (5) and (6). 
Figure 6: Financial shortages financed

by issuing the BoJ notes to black markets

(additional demand for the BoJ notes from black markets/statistical discrepancy )

$100 \%$

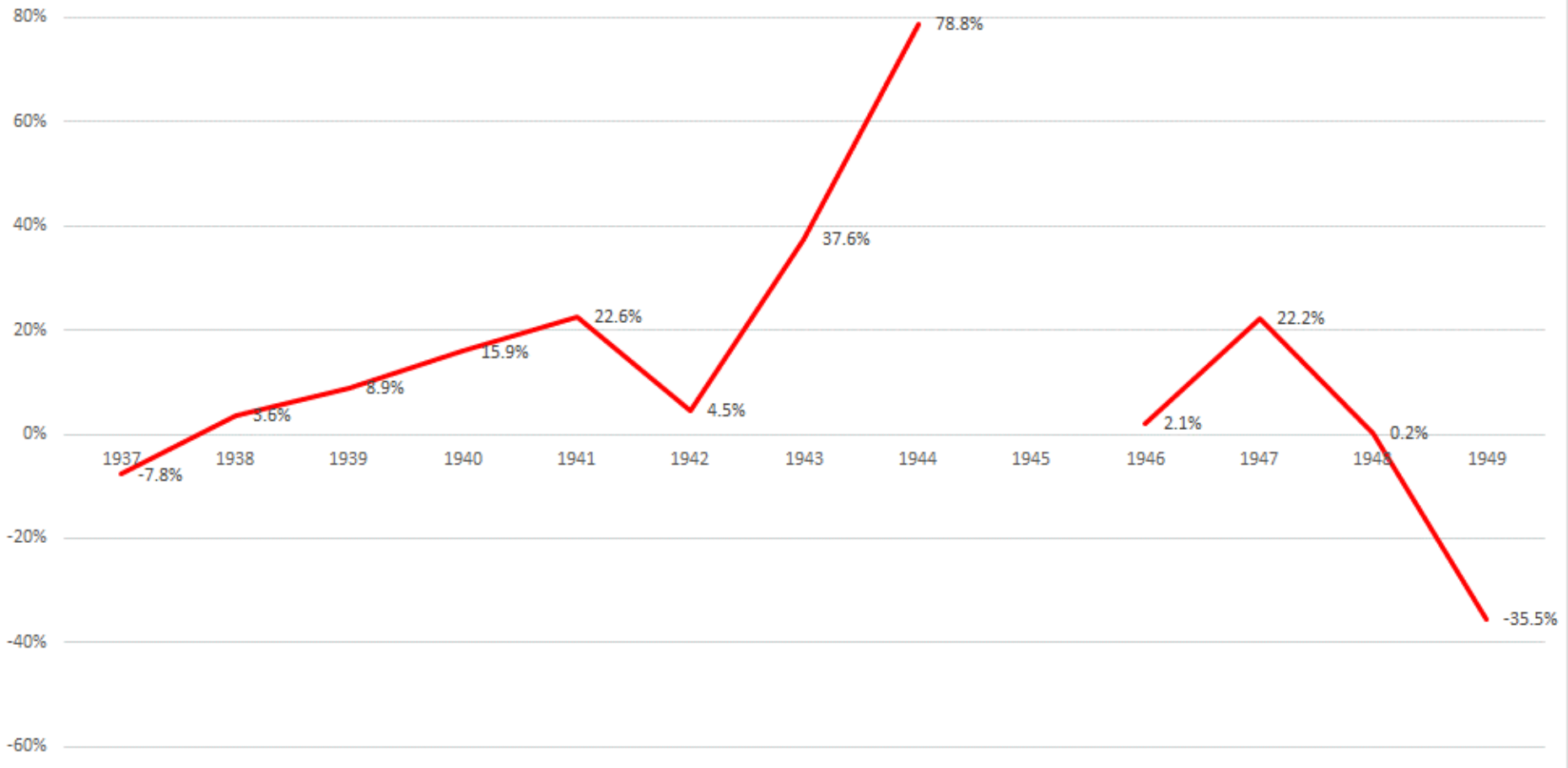

Sources: Bank of Japan (1966), and EPA (1964).

Note (1): The coverage of income leakages by issuing BoJ notes to the black markets is computed using equations (13) and (14), or

$$
\frac{M_{n, t}^{B}-M_{n, t-1}^{B}}{S D_{n, t}}=\frac{\left(M_{n, t}^{S}-M_{n, t-1}^{S}\right)-0.1\left(Y_{n, t}^{E}-Y_{n, t-1}^{E}\right)}{S D_{n, t}} .
$$

